\title{
Ulil norden
}

Control mechanisms for Nordic ship emissions

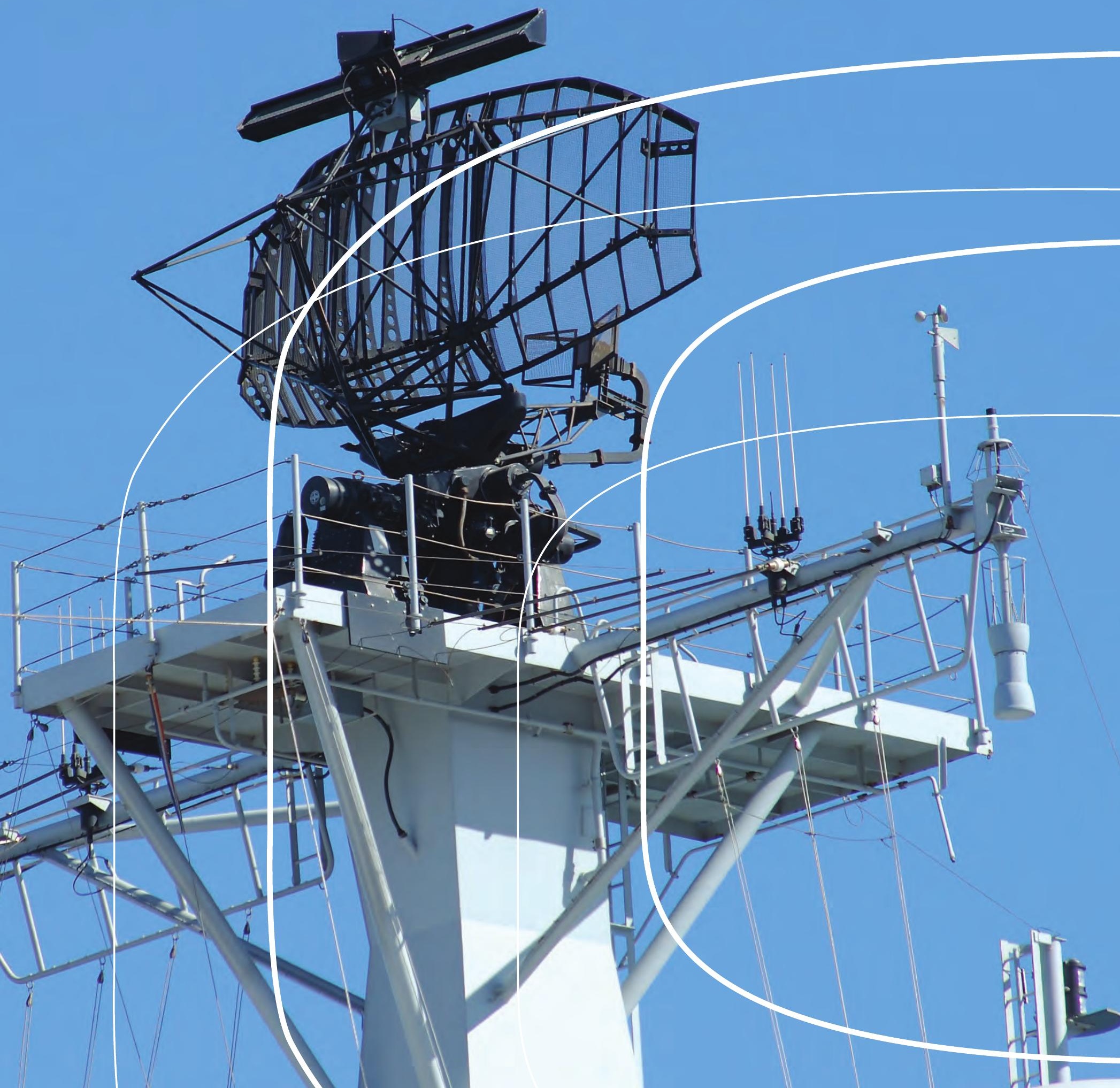



4 norden 



\section{Control mechanisms for Nordic ship emissions}

Kjetil Martinsen (DNV) and Asbjørn Torvanger (Cicero)

TemaNord 2013:518 
Control mechanisms for Nordic ship emissions

Kjetil Martinsen (DNV) and Asbjørn Torvanger (Cicero)

ISBN 978-92-893-2516-5

http://dx.doi.org/10.6027/TN2013-518

TemaNord 2013:518

(C) Nordic Council of Ministers 2013

Layout: Hanne Lebech

Cover photo: ImageSelect

This publication has been published with financial support by the Nordic Council of Ministers. However, the contents of this publication do not necessarily reflect the views, policies or recommendations of the Nordic Council of Ministers.

www.norden.org/en/publications

\section{Nordic co-operation}

Nordic co-operation is one of the world's most extensive forms of regional collaboration, involving Denmark, Finland, Iceland, Norway, Sweden, and the Faroe Islands, Greenland, and Åland.

Nordic co-operation has firm traditions in politics, the economy, and culture. It plays an important role in European and international collaboration, and aims at creating a strong Nordic community in a strong Europe.

Nordic co-operation seeks to safeguard Nordic and regional interests and principles in the global community. Common Nordic values help the region solidify its position as one of the world's most innovative and competitive.

\section{Nordic Council of Ministers}

Ved Stranden 18

DK-1061 Copenhagen K

Phone (+45) 33960200

www.norden.org 


\section{Content}

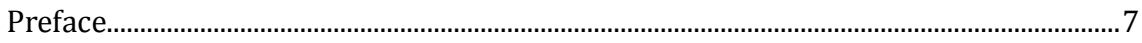

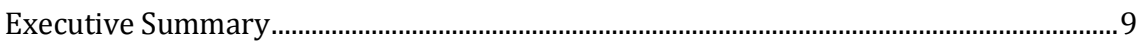

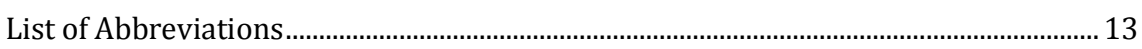

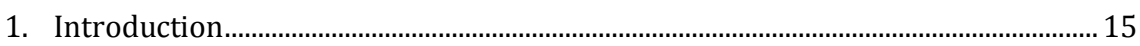

1.1 Approach .................................................................................................................. 15

1.2 Geographical boundaries.............................................................................. 16

2. Nordic ship traffic and emissions............................................................................. 17

2.1 The fleet operating in Nordic waters............................................................ 18

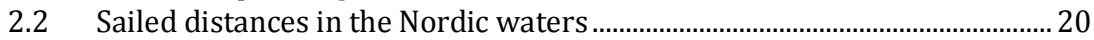

2.3 Baseline emissions in Nordic waters.............................................................. 20

3. Emission components and reduction technologies...................................................... 27

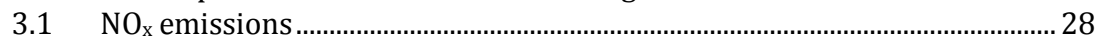

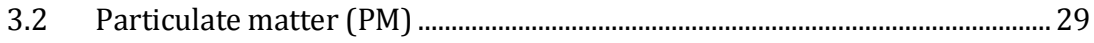

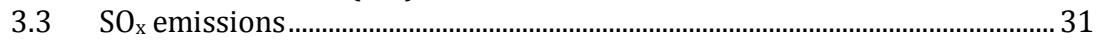

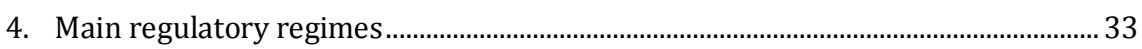

4.1 UN Convention on the Law of the Sea ................................................................ 34

4.2 The International Convention of the Prevention of Pollution from

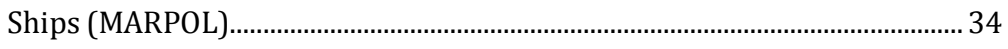

4.3 The EU Air Quality Directive................................................................................ 40

4.4 The 1999 Protocol to Abate Acidification, Eutrophication and Ground-level Ozone (The Gothenburg Protocol) ........................................... 41

$4.5 \quad \mathrm{NO}_{\mathrm{x}}$ fund in Norway (until 2017)...................................................................... 41

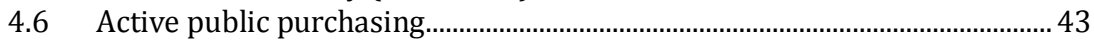

4.7 "Farledsavgift" (Sweden)..................................................................................... 44

5. Potential Emission reduction measures in the Nordic region and

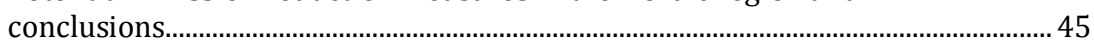

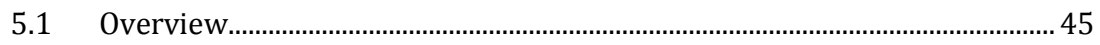

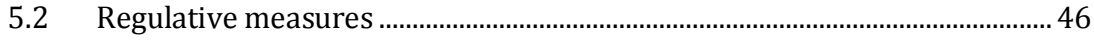

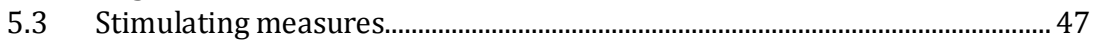

5.4 Market-based measures............................................................................. 50

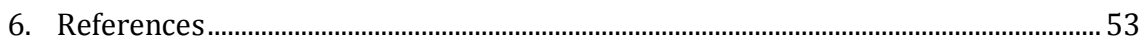

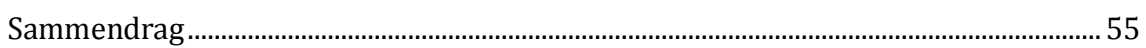

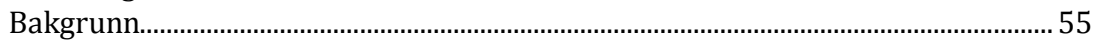

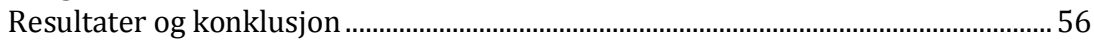





\section{Preface}

Environmentally-hazardous emission to air from shipping has been the subject of political attention for decades. The amount of shipping in the Baltic Sea has increased markedly and, as climate change is causing Arctic sea ice to melt, the issue of ship emissions has also been raised for maritime areas in northern Europe. Nordic co-operation on contingency plans and management of oil spills has been implemented and, in recent years, the issue has also been incorporated in the work of the EU Baltic Sea Strategy.

It is with satisfaction that the final report of the study, Control Mechanisms for Nordic Ship Emissions, is now presented. The study considers emissions to air of nitrogen oxides (Nox), sulphur oxide, and particles from ship engines. The study provides a solid information base for political measures to reduce emissions. And this is crucial.

International regulations on exhaust emissions to air from shipping are lagging far behind the comprehensive regulatory framework for land-based traffic. In particular, sulphur emissions could be reduced by using cleaner bunker oil. This has been implemented through voluntary agreements in ferry traffic, but it has proved very difficult to bring environmental regulations for shipping in international water to the negotiation table, even though the Nordic countries have been pressing for this.

As a supplement to regulations on exhaust emissions to air from ship engines, international marine environmental work has focused on designating especially sensitive maritime areas for greater protection, problems caused by ballast water, and planning for maritime areas. In the environmental sector, the Nordic countries have co-operated in all these focus areas, but have also taken responsibility for a cross-sectoral approach in considering marine resources. This applies to the environmental impact of acidification and eutrophication on, for example, fish stocks.

The Control Mechanisms for Nordic Ship Emissions project also provides greater knowledge about the importance of limiting environmental measures to those areas where they have greatest effects. The project has also provided knowledge about how to tackle the problem of tonnage being transported on vessels that will be operating for another 20-30 years, and what this necessitates in the form of directed measures. One of the conclusions in the report is that the most effective measures would be for the Nordic countries to continue working for the designation of the Baltic Sea and the North Sea as particularly sensitive marine areas.

Another interesting observation is that ferry traffic is responsible for much of the nitrogen oxide emissions to air; consequently, ferry traffic is 
an important target group in the environmental co-operation between authorities and shipping companies.

One important aspect of Nordic co-operation is that the countries can learn from one another. A country at the forefront may be used as a lever in the co-operation. One example is maritime environmental planning, where Norway has come a long way in terms of concrete measures. The Norwegian NOx Fund is another good example of a smart mechanism that stimulates environmental measures, by linking fees for emissions to subsidies for installation of environmentally-sound technology.

Nordic Council of Ministers

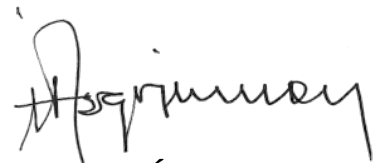

Halldór Ásgrímsson

Secretary General 


\section{Executive Summary}

On behalf of Nordic Council of Ministers DNV has carried out a study on possible control mechanisms for Nordic ship emission. The aim with this project is to assess the base line shipping emissions and reduction potential and the possible controlling mechanisms (both incentives and regulations) available for reducing the emissions to air $\left(\mathrm{NO}_{\mathrm{x}}, \mathrm{PM}\right.$ and $\mathrm{SO}_{\mathrm{x}}$ excluding $\mathrm{CO}_{2}$ ) from shipping within the Nordic region.

\section{Background}

Shipping today operates under a complex set of international and domestic regulations. Traditionally, the leaps in regulations have been event-driven, and in some cases even driven by events outside the sector. Well known examples are the Titanic disaster, which ultimately led to the International Convention for the Safety of Life at Sea (SOLAS) Convention, the Exxon Valdez oil spill, which resulted in the Oil Pollution Act (OPA 90), and the 9/11 attack, which resulted in the International Ship and Port Facility Security (ISPS) Code. However, the environmental regulations have lagged behind those of other industries. This situation is now changing.

The increased focus on both global and local environmental issues in general, combined with the growing realisation of the actual pollution burden imposed by shipping, has led to an upsurge in both international and national regulations. Some are ready and will enter into force in the very near future, while others are still being developed and will have an impact only in the intermediate term.

The key issues that will have a significant regulatory impact in this decade are, broadly speaking, sulphur oxides $\left(\mathrm{SO}_{\mathrm{x}}\right)$, nitrous oxides $\left(\mathrm{NO}_{\mathrm{x}}\right)$ and particles (PM), greenhouse gases (particularly $\mathrm{CO}_{2}$ ) and ballast water.

$\mathrm{SO}_{\mathrm{x}}, \mathrm{NO}_{\mathrm{x}}$ and $\mathrm{PM}$ are all emissions to air that result from the combustion of marine fuels. The local environmental effects of these are generally well known and include acidification and eutrophication, both of which have potentially severe ecosystem impacts and negative health effects on exposed populations. This have in some parts of the world (e.g. the EU and USA) led to strict regulations of emissions from landbased sources. In recognition of shipping becoming a dominant emission source, potentially exceeding land-based sources, emissions have been internationally regulated by IMO through the MARPOL Convention. This gives a combination of general maximum global emission levels and significantly more stringent levels applying to designated sea areas gen- 
erally known as Emission Control Areas (ECAs). The regulations allow emissions to be mitigated by either changing the fuel type or cleaning the exhaust gas.

\section{Results and conclusion}

\section{Measures for reducing $\mathrm{SO}_{x}$ emission}

IMO has already designated the Baltic Sea, the North Sea and the English Channel as $\mathrm{SO}_{\mathrm{x}}$ ECAs. Very soon (2015) the vast majority of vessels operating in Nordic waters will have to comply with strict requirements for $\mathrm{SO}_{\mathrm{x}}$ emission ( $0.1 \%$ sulphur fuel). Beyond this it is difficult to see how the $\mathrm{SO}_{\mathrm{x}}$ emission may be further reduced within the ECA areas when the strictest requirements will come in to force in 2015.

Whether also the Norwegian and the Barents Sea should become $\mathrm{NO}_{\mathrm{x}}$ and $\mathrm{SO}_{\mathrm{x}}$ ECAs has also been addressed. Even though this certainly will result in a reduced overall emission, DNV found no basis for claiming that general MARPOL Annex VI regulations will be efficient means of reducing the $\mathrm{NO}_{\mathrm{x}}$ and $\mathrm{SO}_{\mathrm{x}}$ emissions in the region. The main reason is that these are scarcely populated areas with limited environmental stress.

\section{Measures for reducing $\mathrm{NO}_{x}$ emission}

It is expected that the Baltic Sea and the North Sea will also be designated as $\mathrm{NO}_{\mathrm{x}}$ ECAs in the near future. Hence, all vessels built after 2016 will have to comply with the strictest Tier III emission requirements for $\mathrm{NO}_{\mathrm{x}}$ (representing a 74\% reduction in $\mathrm{NO}_{\mathrm{x}}$ emissions compared to Tier II levels).

However, all vessels built before 2016 will in practice be unaffected by the ECA $\mathrm{NO}_{\mathrm{x}}$ regulations and they will represent a huge number of vessels continuing to operate the next 20-30 years. Therefore, whereas the effect of the $\mathrm{SO}_{\mathrm{x}} \mathrm{ECA}$ implementation will be instantaneous, the $\mathrm{NO}_{\mathrm{x}}$ ECA requirements will gradually take effect over the next 30 years. The ultimate potential for reduction in $\mathrm{NO}_{\mathrm{x}}$ emission from shipping in Nordic waters is around 400,000 tonnes/year moving towards a fully implemented Tier III regime (assuming today's share of Tier III compliant engines is close to zero).

The most important action for the Nordic nations is to actively support the $\mathrm{NO}_{\mathrm{x}}$ ECA application for the Baltic and the North Sea.

It is also clear that any additional regulations/actions should focus on the remaining group of vessels built prior to 2016 and possibly single out particular vessel types particularly suited for regulations. The emission calculations performed in this study revealed that one particular group of vessels dominates the ship emission picture. Passenger vessels, and particularly ferries are relatively few in numbers, but they are re- 
sponsible for around $30 \%$ of the total $\mathrm{NO}_{\mathrm{x}}$ emission from shipping. This is close to 3 times the emission from any of the other vessel groups. These are also vessels which may be subject to licences from the authorities and hence actively stimulating/prioritizing Tier III compliant vessels is potentially an option.

For vessels operating between Nordc ports the Norwegian $\mathrm{NO}_{\mathrm{x}}$ found model may also provide a regulative opportunity. In essence vessels may pay a nominal $\mathrm{NO}_{\mathrm{x}}$ tax based on their emission either to the found (low rate) or to the authorities (high rate). All members that pay a $\mathrm{NO}_{\mathrm{x}}$ tax to the Fund are eligible for financial support for investment with a proven reducing effect on $\mathrm{NO}_{\mathrm{x}}$ emission. Such an extended $\mathrm{NO}_{\mathrm{x}}$ Fund model would have to focus on vessels keel-laid prior to 2016 and consequently support measures on existing vessels such as engine refurbishments and rebuilds, fuel saving measures and retrofit of technologies such as SCR.

LNG is excpected to be a part of the solution to make more vessels meet the Tier III requirements and initiatives for establishing LNG terminals may prove to be crucial.

Looking at the age distribution of the fleet operation in Nordic waters today it is clear that a large proportion is old. This is particularly the case for smaller vessels which are also likely to operate mostly domestically or at least locally. Hence, incentives for replacing aging vessels may be an important way of accelerating the effects of a new regulatory regime. One possibility is to introduce a system with incentives for ship scrapping and replacement, which could be implemented for a limited period. The purpose will be to encourage operators with older vessels to remove their ships from the fleet. Such a system may imply that the owner conducts a commercial scrapping of the ship, and that triggers compensation in the form of a payment from the government.

\section{Measures for reducing $P M / B C$ emission}

Particulate Matters (PM) and Black Carbon (BC) have known negative effects to both health and the environment and while it is desirable to reduce emissions of these substances, most means have uncertain effects. Emissions of PM/BC may most certainly be expected to be reduced with the introduction of a $\mathrm{SO}_{\mathrm{x}}$ ECA (Less sulphur fuel and scrubbers more common), but the connections to the fuel type is not well documented. General fuel savings measures may provide a valuable reductions and LNG fuel will close to eliminates this type of emission. Hence, the most effective means of reduction in particle emission is to stimulate fuel savings and both the implementation of LNG fuelled vessels and to support the establishment of LNG bunkering facilities. 



\section{List of Abbreviations}

- AIS Automatic Identification System

- $\mathrm{CO}_{2}$ Carbondioxide

- ECA Emission Control Area

- EEA European Environmental Agency

- EGR Exhaust Gas Recirculation

- EIA Energy Information Administration

- GHG Green House Gases

- GP The Gothenburg protocol

- IMO International Maritime Organisation

- ISPS Int. Ship and Port Facility Security

- LNG Liquefied Natural Gas

- MEPC Marine Environmental Protection Committee

- $\mathrm{NO}_{\mathrm{x}} \quad$ Nitrogen Oxides

- OPA 90 Oil Pollution Act

- PM Paticulate Matters

- SCR Selective Catalytic Reduction

- SOLAS Convention for the Safety of Life at Sea

- UNCLOS UN Convention on the Law of the Sea 



\section{Introduction}

Emission to air from shipping is a major contributor to air pollution in the Nordic region. Even though cost effective emission reduction technologies are available, few vessels will have incentives to use them.

The aim of this project is to assess baseline shipping emissions and reduction potential, and alternative control mechanisms (both incentives and regulations) available for reducing emissions to air $\left(\mathrm{NO}_{\mathrm{x}}, \mathrm{PM}\right.$ and $\mathrm{SO}_{\mathrm{x}}$ excluding $\mathrm{CO}_{2}$ ) from shipping in the Nordic region. Further, the project assesses the current regulatory regime, international, national or regional in the Nordic countries and discusses the possibilities for joint implementation of the most successful national regulations. The project also looks in to the current marked driven obstacles seen today and what may be done in order to reduce the effects of them. Making use of DNV's unique access to data on shipping activity, the project also looks into the current emissions to air from shipping within the region - and the composition of the fleet trading the region. This makes it possible to tailor regulations/incentives to the main vessel segments, size and age, something we believe is of key importance when setting up such regimes. Using the same data for traffic/emission calculations between the different regions makes regional adaptation possible as well.

DNV has performed this study with assistance from Cicero based on Cicero's extensive knowledge and experience within environmental policies and DNV's knowledge within maritime regulations and operation.

\subsection{Approach}

In this study we have started using our access to AIS (Automatic Identification System) data in order to get an overview of Nordic shipping by:

- Mapping the fleet by ship category and size.

- Establishing the average age of each size/type category.

- Establishing the emissions from each size/type category. 
Following the assessment of the shipping activity the report explains the typical emission components from shipping and the available means of abatement technologies.

The report also describes the current maritime regulatory regime and how this will change over the coming years. This leads to a conclusion regarding within which areas additional regulations are feasible and most effective.

\subsection{Geographical boundaries}

This study is intended to be valid for all Nordic national waters. Unfortunately, the data analysis of ship traffic is based on recorded traffic not including the waters around Iceland and Shetland. However, as these areas represent only fractions of the traffic in the Baltic and the North Sea this approximation is not likely to affect the conclusions drawn from the data. Note also that the Baltic traffic includes the entire Baltic region and not just the Nordic part of the sea. Hence the emission figures derived in this study is higher than than only for the Nordic region of the Baltic.

\section{Figure 1 - The National regions in the Nordic area}

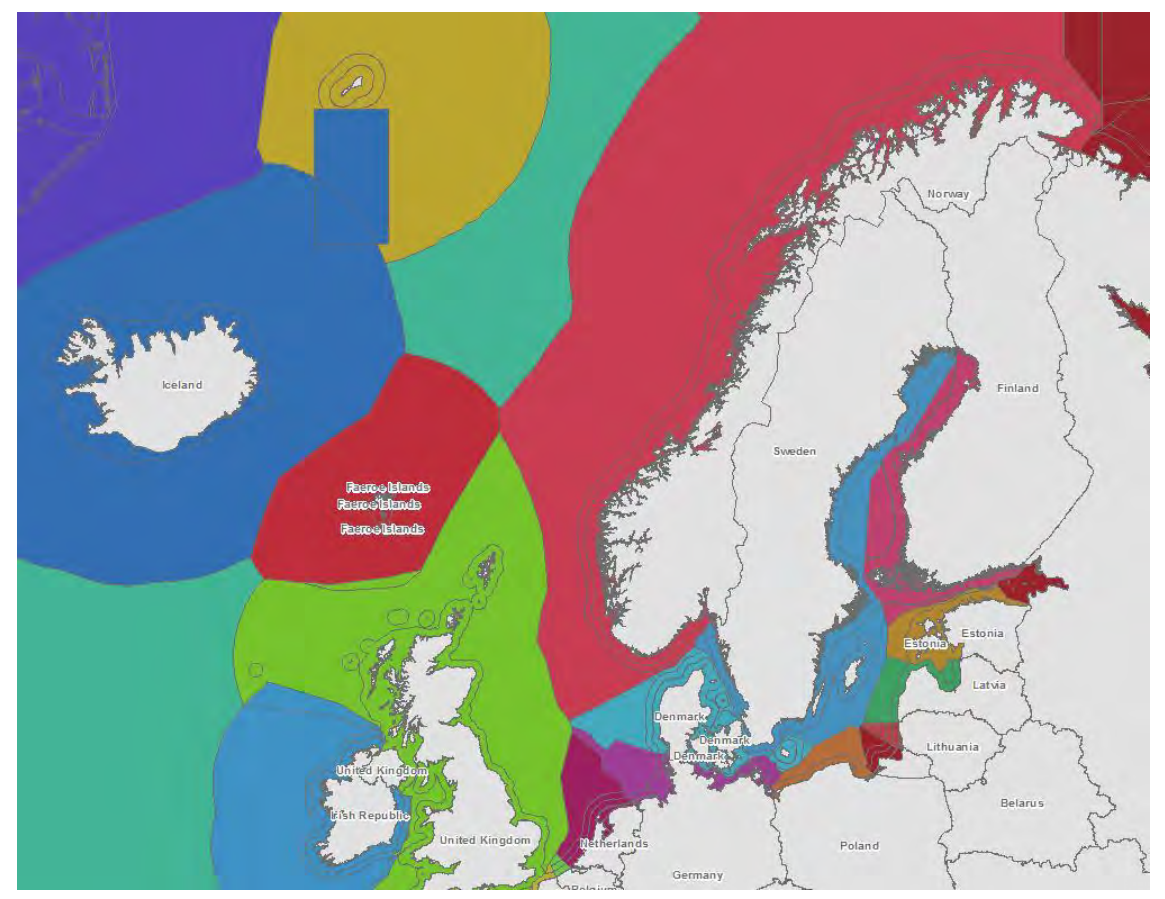




\section{Nordic ship traffic and emissions}

Automatic Identification System (AIS) is an international aid to prevent ship collisions and identify and monitor ships. AIS is made mandatory to vessels over $300 \mathrm{GT}$ on international voyages and $500 \mathrm{BT}$ in domestic trade, and all tankers and passenger ships irrespective of size. Exempt from the requirement to be equipped with AIS are special categories such as warship, naval auxiliary and government-owned or governmentoperated vessels and small craft and leisure boats. Still, a large proportion of the vessels not required to carry a transponder still have them for safety reasons. Hence, we consider the selection of vessels in our dataset to give a good representation of the actual fleet.

DNV is in a unique position in that we have access to AIS data (realtime and historical registration of all ship movements including vessel identity) covering the Baltic, the North Sea, the Norwegian Sea and the Barents Sea, in addition to several other comprehensive data bases with complete ship data.

The structuring, processing and administration of the data is performed through IT@DNV (Data Warehouse - BI Competency Centre), which is a hub for large data sources and a high quality provider of calculations and data management. Through this data warehouse DNV has established the AIS- based environmental accounting system, which is a powerful source for calculation of environmental footprint from ship operations. The key to this is that the IMO number, call sign and vessel name making it possible to connect the information with other high quality ship specific data sources. Thus, DNV is able to calculate sailed distances and emissions within any segment. 
Figure 2 Traffic density in the busiest parts of the Nordic region

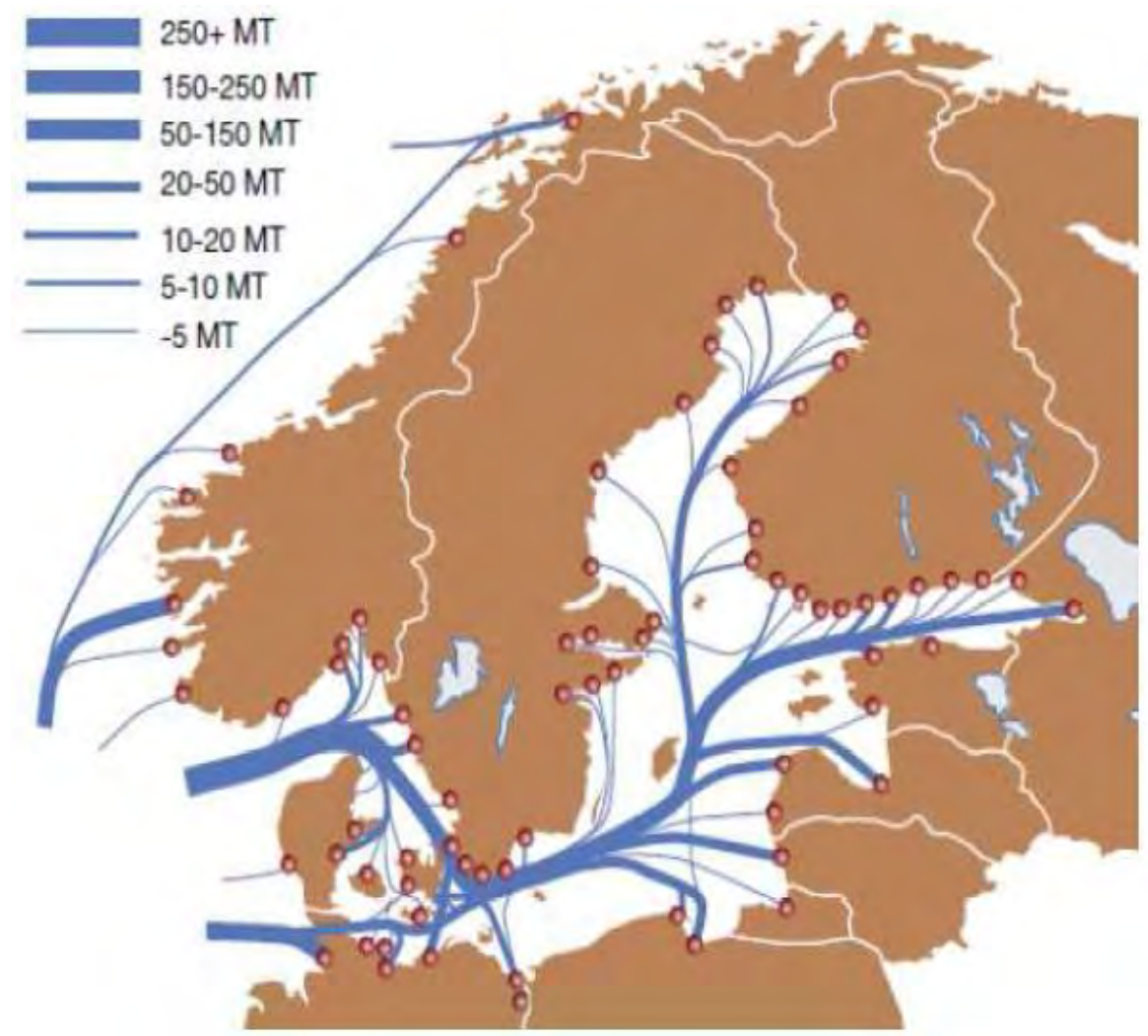

Source: SMA et al., Baltic Maritime Outlook, 2006.

\subsection{The fleet operating in Nordic waters}

From the AIS registration throughout 2011 DNV has analysed the dataset and connected the data to other databases revealing the composition of ship types and sizes sailing the Nordic region. The fleet is presented in our standard $13 \times 7$ matrix as shown in Table 1. 
Table 1- Number of unique vessels found in the Nordic region (through 2011)

\begin{tabular}{|c|c|c|c|c|c|c|c|c|}
\hline $\begin{array}{l}\text { Ship type and size } \\
\text { category (gross ton) }\end{array}$ & $<1,000$ & $\begin{array}{r}1,000- \\
4,999\end{array}$ & $\begin{array}{r}5,000- \\
9,999\end{array}$ & $\begin{array}{r}10,000- \\
24,999\end{array}$ & $\begin{array}{r}25,000- \\
49,999\end{array}$ & $\begin{array}{r}50,000- \\
99,999\end{array}$ & $>100,000$ & $\begin{array}{r}\text { All } \\
\text { sizes }\end{array}$ \\
\hline Oil tankers & 67 & 131 & 19 & 26 & 266 & 408 & 29 & 946 \\
\hline Chemical and product & 24 & 329 & 269 & 455 & 300 & 2 & & 1,379 \\
\hline Gas tankers & 3 & 101 & 36 & 44 & 36 & 15 & 18 & 253 \\
\hline Bulk carries & 8 & 51 & 37 & 646 & 727 & 198 & 15 & 1,682 \\
\hline General cargo & 164 & 1,954 & 528 & 275 & 73 & & & 2,994 \\
\hline Container vessels & & 35 & 187 & 163 & 266 & 362 & 135 & 1,148 \\
\hline Ro Ro vessels & 8 & 18 & 66 & 132 & 120 & 260 & & 604 \\
\hline Reefers & 2 & 60 & 137 & 103 & & & & 302 \\
\hline Passenger & 481 & 208 & 56 & 120 & 131 & 43 & 12 & 1,051 \\
\hline Offshore supply vessels & 69 & 397 & 67 & & & & & 533 \\
\hline Other offshore vessels & 108 & 51 & 32 & 41 & 6 & 18 & 4 & 260 \\
\hline Other activities & 1,427 & 400 & 96 & 104 & 22 & & 2 & 2,051 \\
\hline Fishing vessels & 1,024 & 346 & 22 & & & & & 1,392 \\
\hline Undefined & 8,717 & & & & & & & 8,721 \\
\hline Total & 12,102 & 4,081 & 1,552 & 2,109 & 1,947 & 1,306 & 215 & 23,316 \\
\hline
\end{tabular}

As can be seen in Table 1 and Figure 2 the predominant vessel type is general cargo vessels followed by a group of vessels referred to as "other activities" (tugs, service, research, naval and predominantly small vessels outside the main ship categories).

Figure 2 - Number of vessels and vessel types in Nordic waters

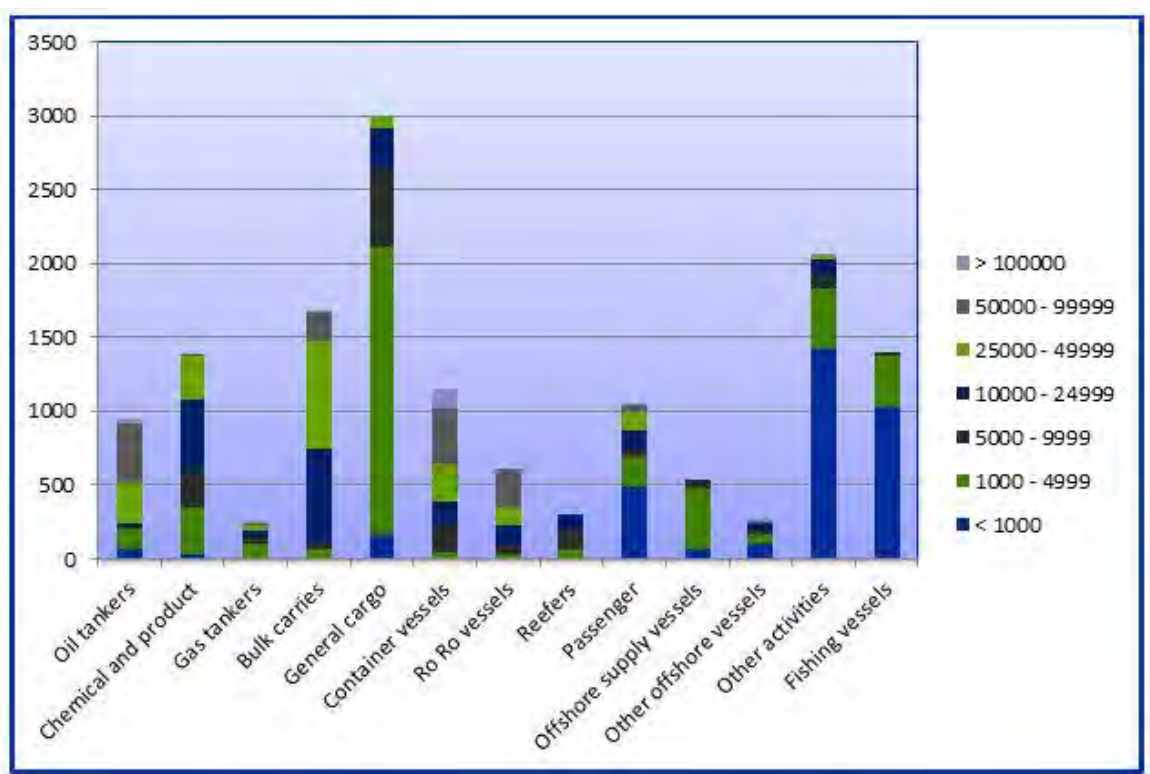




\subsection{Sailed distances in the Nordic waters}

Table 2- Sailed distances in Nordic waters with \% of total distance

\begin{tabular}{|c|c|c|c|c|c|c|}
\hline \multirow[t]{3}{*}{ Ship type } & \multicolumn{6}{|c|}{ Sailed distance - 2011} \\
\hline & \multicolumn{2}{|c|}{ Baltic Sea } & \multicolumn{2}{|c|}{ North Sea - outside Norway } & \multicolumn{2}{|c|}{ Norw. Ec. Sector } \\
\hline & $1,000 \times \mathrm{nm}$ & $\%$ & $1,000 \times \mathrm{nm}$ & $\%$ & $1,000 \times \mathrm{nm}$ & $\%$ \\
\hline Oil tankers & $6,178,386$ & $2.1 \%$ & $1,763,863$ & $0.6 \%$ & $1,934,281$ & $0.7 \%$ \\
\hline Chemical and product & $13,239,484$ & $4.5 \%$ & $3,579,566$ & $1.2 \%$ & $3,331,758$ & $1.1 \%$ \\
\hline Gas tankers & 831,032 & $0.3 \%$ & 755,931 & $0.3 \%$ & $1,088,307$ & $0.4 \%$ \\
\hline Bulk carries & $6,372,714$ & $2.2 \%$ & $2,130,010$ & $0.7 \%$ & $3,282,628$ & $1.1 \%$ \\
\hline General cargo & $38,672,813$ & $13.1 \%$ & $6,257,664$ & $2.1 \%$ & $15,053,485$ & $5.1 \%$ \\
\hline Container vessels & $11,775,795$ & $4.0 \%$ & $3,609,107$ & $1.2 \%$ & 723,236 & $0.2 \%$ \\
\hline Ro Ro vessels & $9,141,838$ & $3.1 \%$ & $3,066,428$ & $1.0 \%$ & 877,858 & $0.3 \%$ \\
\hline Reefers & $2,008,157$ & $0.7 \%$ & 545,814 & $0.2 \%$ & $1,472,180$ & $0.5 \%$ \\
\hline Passenger & $21,460,534$ & $7.3 \%$ & $1,461,033$ & $0.5 \%$ & $11,377,326$ & $3.9 \%$ \\
\hline Offshore supply vessels & 755,983 & $0.3 \%$ & 829,606 & $0.3 \%$ & $3,029,102$ & $1.0 \%$ \\
\hline Other offshore vessels & 208,731 & $0.1 \%$ & 351,912 & $0.1 \%$ & 582,712 & $0.2 \%$ \\
\hline Other activities & $6,657,207$ & $2.3 \%$ & $1,534,558$ & $0.5 \%$ & $4,630,387$ & $1.6 \%$ \\
\hline Fishing vessels & $2,054,425$ & $0.7 \%$ & $2,040,116$ & $0.7 \%$ & $9,806,415$ & $3.3 \%$ \\
\hline Unknown & $22,059,085$ & $7.5 \%$ & $2,891,511$ & $1.0 \%$ & $65,995,997$ & $22.3 \%$ \\
\hline Total & $141,416,185$ & $47.9 \%$ & $30,817,121$ & $10.4 \%$ & $123,185,670$ & $41.7 \%$ \\
\hline
\end{tabular}

\subsection{Baseline emissions in Nordic waters}

Emissions to air resulting from ship traffic is calculated and tabulated as presented in Table 3 and Figure 3. Note that the calculations are performed based on data from each individual ship, and integrated up to fleet level. This includes specific fuel consumption (based on individual machinery performance), the vessel speed over ground in relation to design speed of the vessel. From this we may derive the fuel consumption for any given period and the resulting emission to air. This is performed for all vessels in the selection and the results are tabulated in Table 3.

Table 3 - Total emission to air from shipping in Nordic waters - 2011

\begin{tabular}{|c|c|c|c|c|c|c|c|}
\hline \multirow[t]{2}{*}{ Ship types } & \multicolumn{7}{|c|}{ Emissions - tons per year - 2011 - Nordic waters } \\
\hline & $\begin{array}{r}\text { Fuel } \\
\text { (tons) }\end{array}$ & $\begin{array}{r}\mathrm{CO}_{2} \\
(1,000 \text { ton })\end{array}$ & $\begin{array}{r}\mathrm{NO}_{x} \\
\text { (tons) }\end{array}$ & $\begin{array}{r}\mathrm{SO}_{2} \\
\text { tons) }\end{array}$ & $\begin{array}{r}\text { PM } \\
\text { (tons) }\end{array}$ & $\begin{array}{r}\text { Black } \\
\text { Carbon } \\
\text { (tons) }\end{array}$ & $\begin{array}{r}\text { Organic } \\
\text { Carbon } \\
\text { (tons) }\end{array}$ \\
\hline Oil tankers & $1,215,561$ & 2,148 & 47,684 & 9,737 & 3,948 & 121 & 409 \\
\hline Chemical and product & $1,589,532$ & 2,725 & 52,891 & 6,849 & 4,190 & 154 & 520 \\
\hline Gas tankers & 178,907 & 375 & 6,807 & 899 & 537 & 21 & 72 \\
\hline Bulk carries & 978,227 & 1,807 & 40,850 & 6,408 & 4,437 & 102 & 344 \\
\hline General cargo & $1,732,082$ & 3,051 & 47,422 & 4,089 & 3,733 & 173 & 585 \\
\hline Container vessels & $1,534,200$ & 2,489 & 50,224 & 6,927 & 3,580 & 141 & 475 \\
\hline Ro Ro vessels & $1,468,742$ & 2,384 & 53,852 & 8,147 & 4,075 & 134 & 454 \\
\hline Reefers & 223,390 & 404 & 6,862 & 753 & 532 & 23 & 77 \\
\hline Passenger & $3,777,101$ & 6,573 & 143,485 & 22,436 & 11,601 & 371 & 1,252 \\
\hline Offshore supply vessels & 383,510 & 977 & 14,009 & 555 & 736 & 56 & 187 \\
\hline Other offshore vessels & 105,401 & 253 & 3,918 & 295 & 306 & 14 & 48 \\
\hline Other activities & 536,123 & 1,013 & 14,624 & 734 & 1,618 & 58 & 194 \\
\hline Fishing vessels & 263,065 & 681 & 9,522 & 387 & 910 & 39 & 131 \\
\hline Total & $13,985,841$ & 24,880 & 492,149 & 68,216 & 40,204 & 1,406 & 4,750 \\
\hline
\end{tabular}


Figure 3 - Emission components from vessels in Nordic waters

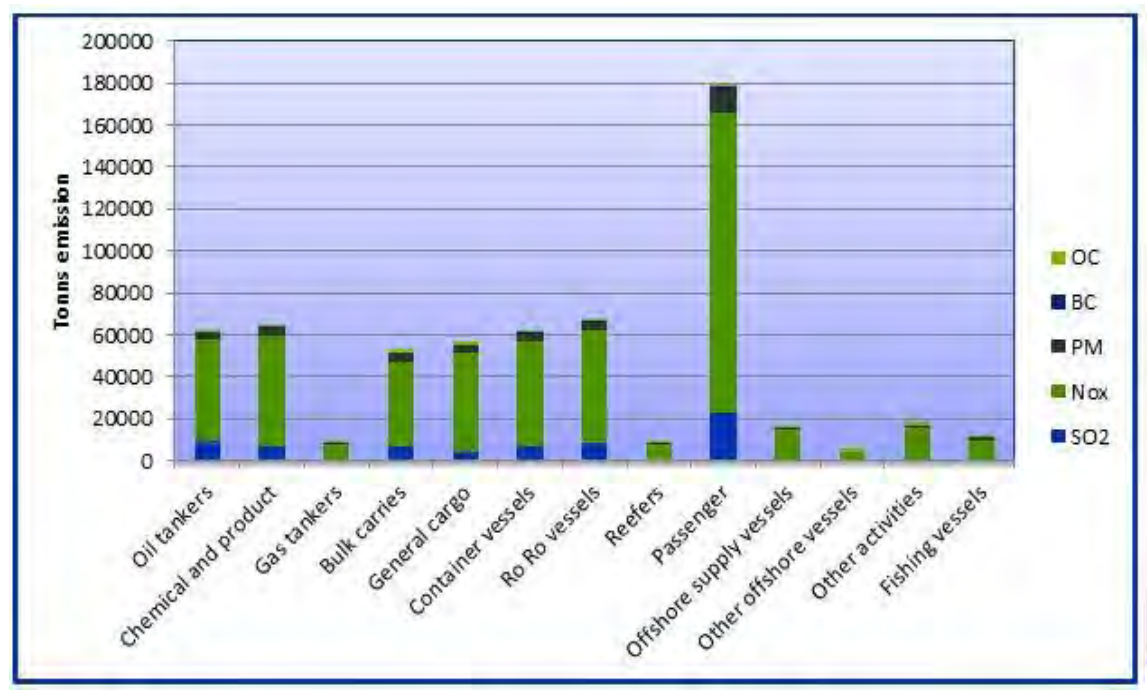

New and strict regulations putting strict limitations on both $\mathrm{NO}_{\mathrm{x}}$ and $\mathrm{SO}_{\mathrm{x}}$ emissions are due. However the implications will be very different for the two emission components. This is because the $\mathrm{SO}_{\mathrm{x}}$ emission is regulated with the available consumables whereas the $\mathrm{NO}_{\mathrm{x}}$ emission is controlled by implementing requirements to the future vessels as the existing ones are phased out.

From 2015, $\mathrm{SO}_{2}$ emissions will be considerably reduced as all vessels in the Baltic and North Sea will have to comply with the $\mathrm{SO}_{\mathrm{x}} \mathrm{ECA}$ requirements. Even though the regulation imposes a reduction of close to $96 \%$ as compared to the world average $(2.4 \%$ to $0.1 \%$ sulphur) the net reduction may be expected to be relatively smaller as a large proportion of the smaller vessels operate on distillate fuel already with a sulphur content close to - or within - the future SECA requirement.

On the other hand, when the Baltic and North Sea become $\mathrm{NO}_{\mathrm{x}}$ Emission Control Area it will likely be a long period before this will affect the $\mathrm{NO}_{\mathrm{x}}$ emission unless additional regulations are introduced, (see Figure 12).

Note also the dominant role of passenger vessels with respect to $\mathrm{NO}_{\mathrm{x}}$ and PM emissions, despite the fact that they are not dominant in number or sailed distance. The main sources are the large passenger ferries operating the region with large machineries, high utilization and operate at high speed. 
Table 4 - The average age (years) of vessels found in the Nordic region (through 2011)

\begin{tabular}{|c|c|c|c|c|c|c|c|c|}
\hline $\begin{array}{l}\text { Ship type and size } \\
\text { category (gross ton) }\end{array}$ & $<1,000$ & $\begin{array}{r}1,000- \\
4,999\end{array}$ & $\begin{array}{r}5,000- \\
9,999\end{array}$ & $\begin{array}{r}10,000- \\
24,999\end{array}$ & $\begin{array}{r}25,000- \\
49,999\end{array}$ & $\begin{array}{r}50,000- \\
99,999\end{array}$ & $>100,000$ & $\begin{array}{r}\text { All } \\
\text { sizes }\end{array}$ \\
\hline Oil tankers & 34.3 & 25.4 & 13.2 & 12.8 & 6.2 & 6.9 & 9.2 & 11.6 \\
\hline Chemical and product & 15.7 & 12.1 & 7.8 & 7.5 & 6.2 & 7.5 & & 8.5 \\
\hline Gas tankers & 39.3 & 14.4 & 10.3 & 12.5 & 6.9 & 14.0 & 4.4 & 12.0 \\
\hline Bulk carries & 40.0 & 32.7 & 12.3 & 13.8 & 9.5 & 5.6 & 16.8 & 11.7 \\
\hline General cargo & 38.5 & 17.6 & 10.3 & 13.2 & 16.8 & & & 17.0 \\
\hline Container vessels & & 15.7 & 9.6 & 8.7 & 9.7 & 8.1 & 3.0 & 8.4 \\
\hline Ro Ro vessels & 31.4 & 23.8 & 20.1 & 14.8 & 10.4 & 8.4 & & 12.3 \\
\hline Reefers & 35.0 & 25.0 & 21.2 & 22.2 & & & & 22.4 \\
\hline Passenger & 27.6 & 21.4 & 18.1 & 23.4 & 15.1 & 10.0 & 5.6 & 22.9 \\
\hline Offshore supply vessels & 24.3 & 13.5 & 3.6 & & & & & 13.7 \\
\hline Other offshore vessels & 32.1 & 16.0 & 11.4 & 9.7 & 14.8 & 14.9 & 18.8 & 21.1 \\
\hline Other activities & 23.2 & 22.5 & 18.8 & 20.6 & 11.5 & & 26.0 & 22.6 \\
\hline Fishing vessels & 24.7 & 20.6 & 21.1 & & & & & 23.6 \\
\hline Total & 30.5 & 20.1 & 13.7 & 14.5 & 10.7 & 9.4 & 12.0 & 16.0 \\
\hline
\end{tabular}

Table 4 and Figure 4 show the age composition for the vessels trafficking the Nordic through 2011. As can be seen from the material it is a trend in our material that the smaller vessels are generally older than the larger ones. Also the more complicated and advanced vessel types are generally older than the more crude tankers and bulk carriers.

Figure 4 - Average age of vessels categories in Nordic waters

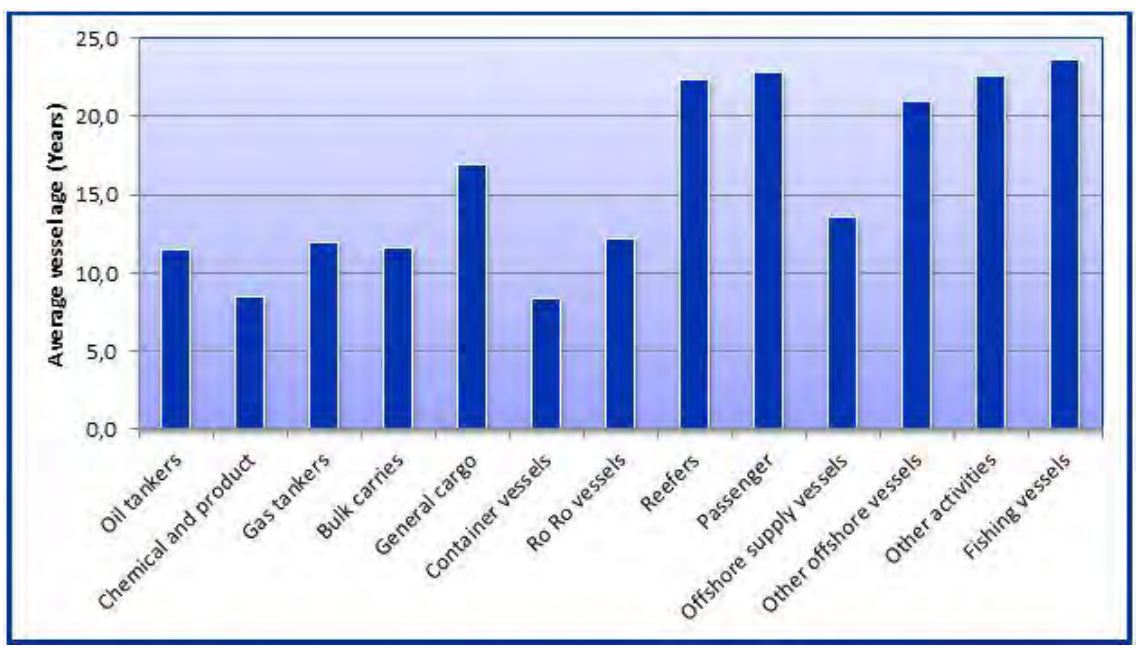

It is clear that an accelerated reduction in $\mathrm{NO}_{\mathrm{x}}$ (and also PM) emissions in the Nordic region will require either a major renewal of the fleet op- 
erating the region or additional local requirements addressing the $\mathrm{NO}_{\mathrm{x}}$ emission by alternative means.

Table 5 shows that the majority of $\mathrm{NO}_{\mathrm{x}}$ emissions come from the vessels younger than 20 years. Still, there also are considerable emissions from the $20+$ year old vessels and a potential $80-90 \%$ reduction of this share in the Baltic and the North Sea is available through replacing the tonnage with modern Tier III vessels.

Table 5 - NO $\mathrm{x}_{\mathrm{x}}$ emission (tons) from each ship category and age group in the Nordic region (through 2011)

\begin{tabular}{lrrrrrrr}
\hline Ship type and age group & $\mathbf{0 - 9}$ & $\mathbf{1 0 - 1 9}$ & $\mathbf{2 0 - 2 9}$ & $\mathbf{3 0 - 3 9}$ & $\mathbf{4 0 - 5 0}$ & $\mathbf{> 5 0}$ & Total \\
\hline Oil tankers & 36,510 & 9,866 & 519 & 387 & 376 & 25 & 47,684 \\
Chemical and product & 38,760 & 10,992 & 2498 & 445 & 196 & 0 & 52,891 \\
Gas tankers & 3,859 & 2,125 & 710 & 97 & 6 & 9 & 6,807 \\
Bulk carries & 20,640 & 9,082 & 5,957 & 4,996 & 173 & 1 & 40,850 \\
General cargo & 13,283 & 18,260 & 9,300 & 5,631 & 893 & 55 & 47,422 \\
Container vessels & 32,031 & 13,248 & 3,612 & 1,333 & & & 50,224 \\
Ro Ro vessels & 25,818 & 17,672 & 5,678 & 4,519 & 164 & & 53,852 \\
Reefers & 593 & 1,411 & 3,674 & 1,184 & & 6,862 \\
Passenger & 52,406 & 47,325 & 27,994 & 13,522 & 1,677 & 560 & 143,485 \\
Offshore supply vessels & 10,536 & 1,498 & 1,537 & 423 & 11 & 4 & 14,009 \\
Other offshore vessels & 2,052 & 954 & 364 & 209 & 316 & 23 & 3,918 \\
Other activities & 3,705 & 3,345 & 3,556 & 2,940 & 810 & 267 & 14,624 \\
Fishing vessels & 1,551 & 3,663 & 2,531 & 1,158 & 488 & 131 & 9,522 \\
Total & 241,745 & 139,443 & 67,931 & 36,843 & 5,111 & 1,076 & 492,148 \\
\hline
\end{tabular}

Figure 5 - $\mathrm{NO}_{x}$ emission per vessel category in Nordic waters

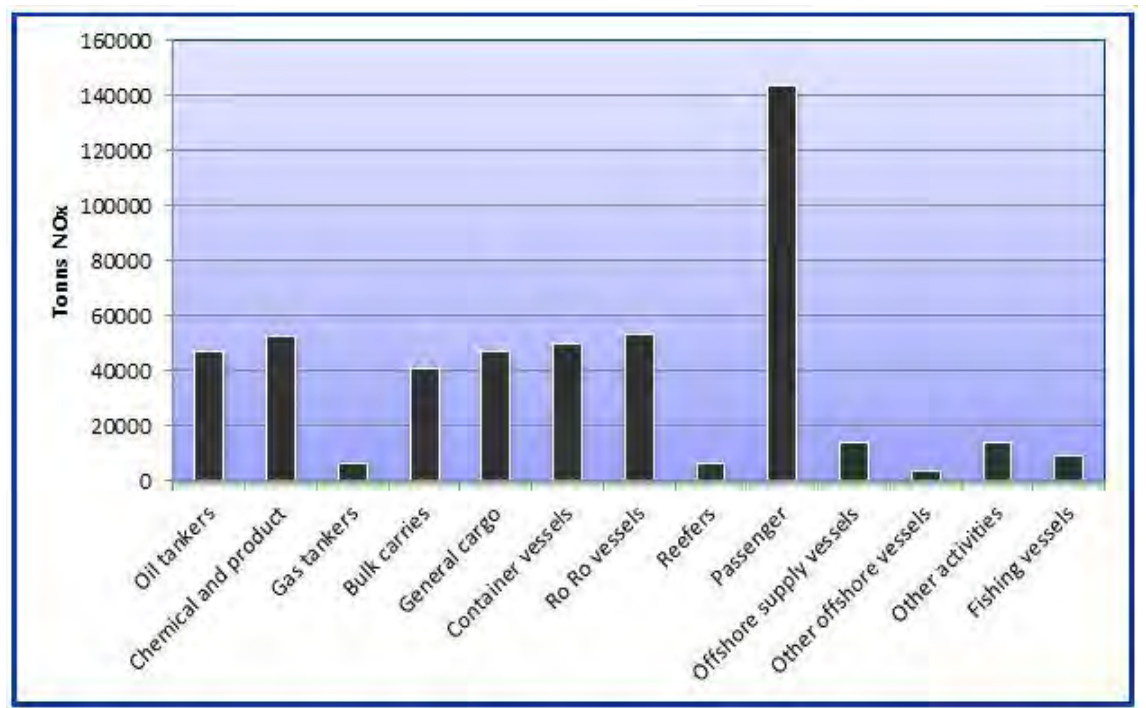


Table 6 - PM emission (tonnes) from each ship category and age group in the Nordic region (through 2011)

\begin{tabular}{lrrrrrrr}
\hline Ship type and age group & $\mathbf{0 - 9}$ & $\mathbf{1 0 - 1 9}$ & $\mathbf{2 0 - 2 9}$ & $\mathbf{3 0 - 3 9}$ & $\mathbf{4 0 - 5 0}$ & $\mathbf{5 0}$ & Total \\
\hline Oil tankers & 3,141 & $\mathbf{7 3 1}$ & 23 & 11 & 16 & 1 & 3,924 \\
Chemical and product & 2,839 & 609 & 105 & 13 & 5 & 0 & 3,571 \\
Gas tankers & 228 & 118 & 37 & 3 & 0 & 0 & 385 \\
Bulk carries & 1,864 & 812 & 514 & 365 & 5 & 0 & 3,561 \\
General cargo & 332 & 469 & 242 & 151 & 24 & 1 & 1,219 \\
Container vessels & 2,136 & 832 & 312 & 117 & & & 3,396 \\
Ro Ro vessels & 2,327 & 1,504 & 413 & 385 & 4 & & 4,633 \\
Reefers & 20 & 52 & 170 & 82 & & & 324 \\
Passenger & 4,478 & 3,814 & 2,330 & 1,094 & 112 & 32 & 11,861 \\
Offshore supply vessels & 276 & 40 & 42 & 11 & 0 & 0 & 370 \\
Other offshore vessels & 51 & 24 & 11 & 5 & 21 & 1 & 113 \\
Other activities & 98 & 87 & 94 & 77 & 22 & 7 & 386 \\
Fishing vessels & 42 & 99 & 69 & 31 & 13 & 4 & 258 \\
Total & 17,832 & 9,191 & 4,361 & 2,346 & 222 & 46 & 34,000 \\
\hline
\end{tabular}

\section{Figure 6 PM emission per vessel category in Nordic waters}

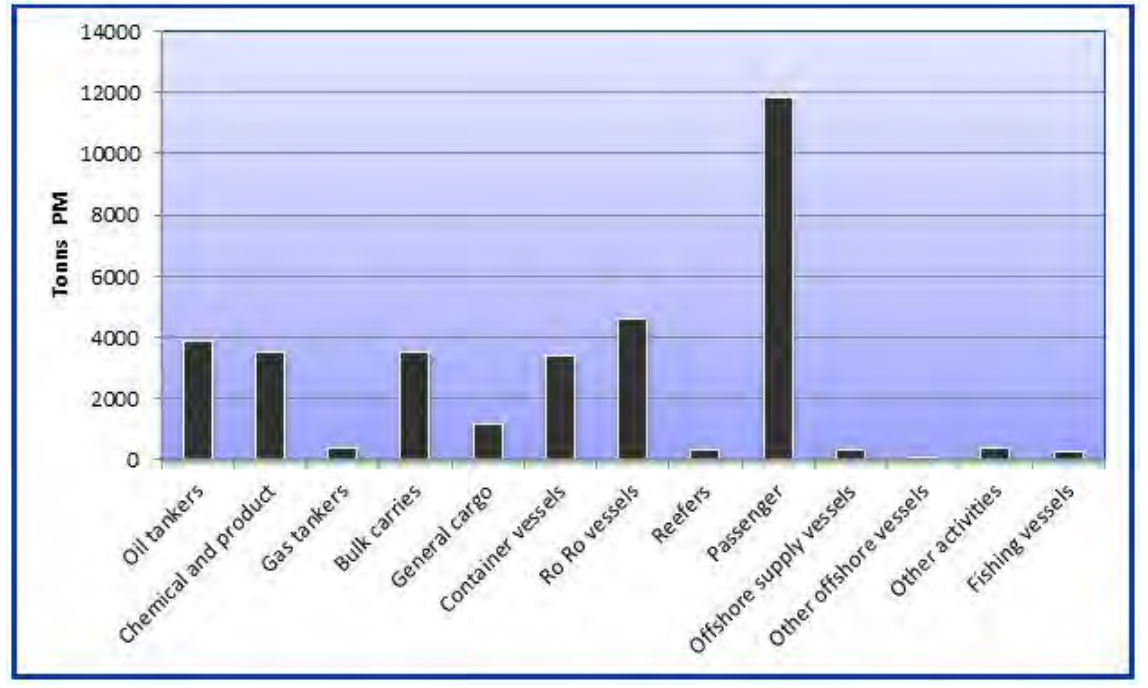

Like in Table 5 and Figure 5 for $\mathrm{NO}_{\mathrm{x}}$ emission, PM follows very much the pattern as seen in Table 6 and Figure 6. Passenger vessels dominate the emission picture with nearly triple the emission of the second largest contributor oil tankers. 
Table 7 - $\mathrm{SO}_{\mathrm{x}}$ emission (tons) from each ship category and age group in the Nordic region (through 2011)

\begin{tabular}{lrrrrrrr}
\hline Ship type and age group & $\mathbf{0 - 9}$ & $\mathbf{1 0 - 1 9}$ & $\mathbf{2 0 - 2 9}$ & $\mathbf{3 0 - 3 9}$ & $\mathbf{4 0 - 5 0}$ & $\mathbf{5 0}$ & Total \\
\hline Oil tankers & 7,713 & 1,885 & 62 & 31 & 45 & 2 & 9,737 \\
Chemical and product & 5,238 & 1,288 & 266 & 43 & 15 & 0 & 6,849 \\
Gas tankers & 555 & 251 & 83 & 9 & 0 & 0 & 899 \\
Bulk carries & 3392 & 1,423 & 904 & 676 & 14 & 0 & 6,408 \\
General cargo & 1,127 & 1,597 & 814 & 477 & 72 & 2 & 4,089 \\
Container vessels & 4,458 & 1,727 & 543 & 198 & & & 6,927 \\
Ro Ro vessels & 4,014 & 2,646 & 810 & 664 & 13 & & 8,147 \\
Reefers & 59 & 140 & 398 & 156 & & 753 \\
Passenger & 8,819 & 7,206 & 4,268 & 1,891 & 197 & 55 & 22,436 \\
Offshore supply vessels & 415 & 60 & 62 & 17 & 0 & 0 & 555 \\
Other offshore vessels & 145 & 58 & 25 & 11 & 56 & 1 & 295 \\
Other activities & 177 & 164 & 200 & 149 & 33 & 11 & $\mathbf{7 3 4}$ \\
Fishing vessels & 63 & 149 & 103 & 47 & 20 & 5 & 387 \\
Total & 36,174 & 18,595 & 8,537 & 4,368 & 465 & 76 & 68,216 \\
\hline
\end{tabular}

Figure $7 \mathrm{SO}_{x}$ emission per vessel category in Nordic waters

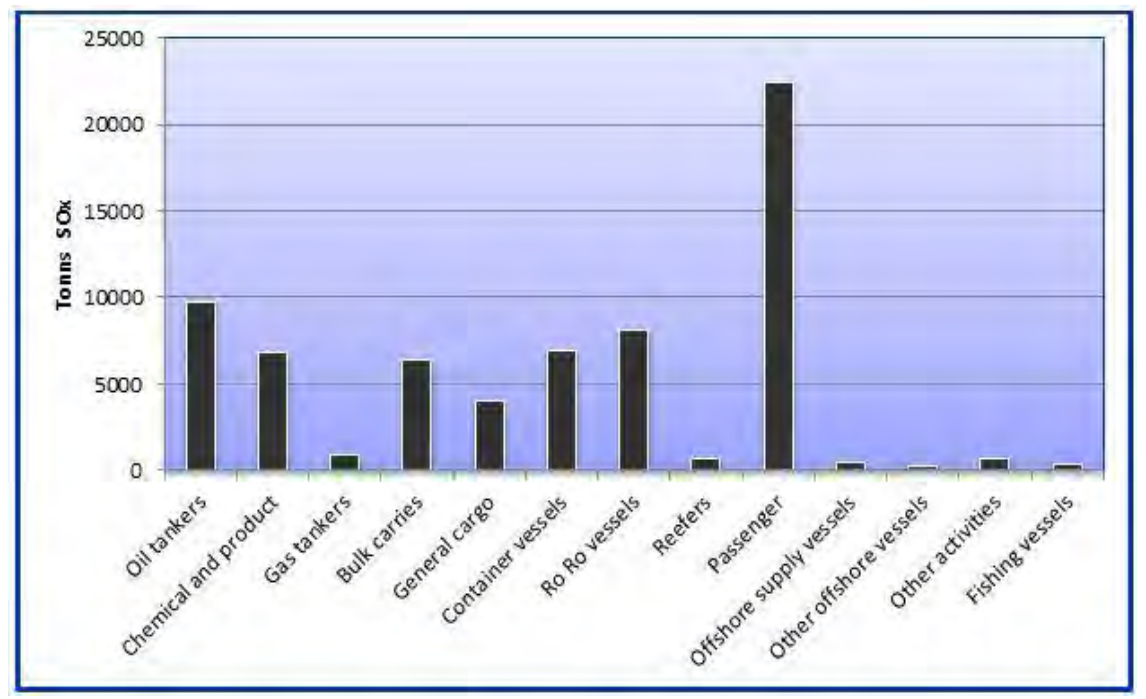





\section{Emission components and reduction technologies}

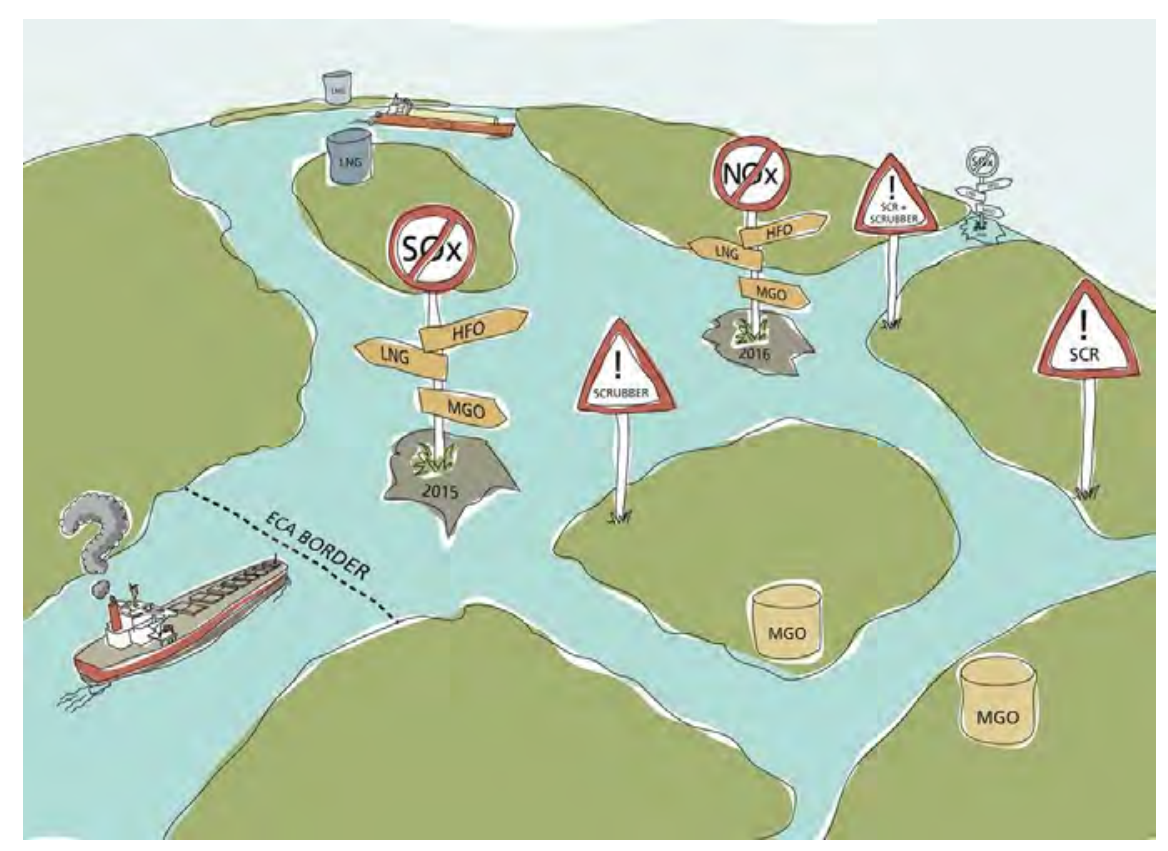

There are several technically and economically feasible measures to reduce shipping emissions. These techniques are also very costeffective compared to further emission reduction costs for land-based sources that have achieved a higher degree of maturity.

The methods for $\mathrm{SO}_{\mathrm{x}}$ emissions reduction are switching from fuels with high to low-sulphur content, and the introduction of the seawater scrubbing technology. For nitrogen oxides abatement, the most promising methods are internal engine modifications, water injection techniques and Exhaust Gas Recirculation (EGR), and Selective Catalytic Reduction (SCR) systems. Particulate matter emissions are reduced as a consequence of the sulphur dioxide reduction measures and also oxidation catalysts and particulate filters can be used.

A modal shift towards the use of Liquefied Natural Gas (LNG) as fuel will have a significant positive effect on all emission components and even remove some entirely. However, the infrastructure for bunkering is a critical factor for the growth of LNG as an energy source for future shipping [Ref /6/]. 
Greenhouse gas emissions are not a part of this study and thus the report will concentrate on the parameters nitrogen oxides $\left(\mathrm{NO}_{\mathrm{x}}\right)$, sulphur oxides $\left(\mathrm{SO}_{\mathrm{x}}\right)$ and $\mathrm{PM}$.

\section{$3.1 \mathrm{NO}_{\mathrm{x}}$ emissions}

\subsubsection{NO $\mathrm{N}_{x}$ and effects on health and the environment}

Nitrogen dioxide is a reactive gas that is mainly formed by oxidation of nitrogen monoxide (NO). High temperature combustion processes (e.g. those occurring in car engines and power plants) are the major sources of nitrogen oxides, $\mathrm{NO}_{\mathrm{x}}$, the term used to describe the sum of $\mathrm{NO}$ and $\mathrm{NO}_{2}$. NO makes up the majority of $\mathrm{NO}_{\mathrm{x}}$ emissions.

$\mathrm{NO}_{\mathrm{x}}$ emission contributes to the acidification of aquatic and terrestrial environments and occurs through deposition of sulphur and nitrogen compounds from the air and causes damage to forests, fish and other plant and animal life. Deposition of sulphur is still of primary importance for acidification in the Nordic region. However, the relative importance of nitrogen as a source of acidification will increase with the general decrease in sulphur emissions.

Nitrogen compounds function as a fertilizer for plants and algae. The majority comes from the atmosphere (wet and dry deposition) and by biological nitrogen fixation. Increased access to nitrogen from air pollution $\left(\mathrm{NO}_{\mathrm{x}}\right)$ can lead to fertilization effects such as increased biomass production, changes in competitive relationships between plants, and changes in species composition towards more nitrogen demanding vegetation.

Particles and $\mathrm{NO}_{\mathrm{x}}$ are the main problems regarding the air quality in the Nordic region. $\mathrm{NO}_{2}$ from combustion processes contribute to impaired lung function and increased susceptibility to respiratory infections and allergies. $\mathrm{NO} / \mathrm{NO}_{2}$ also form secondary particles that are included in the total particle pollution [Ref /8/].

\subsection{2 $\mathrm{NO}_{\mathrm{x}}$ emission reduction technologies}

The amount of $\mathrm{NO}_{\mathrm{x}}$ formed depends on the combustion temperature, premixing of fuel and air, and duration of the fuel in the cylinder. $\mathrm{NO}_{\mathrm{x}}$ can be abated by measures which reduce the formation of $\mathrm{NO}_{\mathrm{x}}$ during the combustion process, or by neutralizing $\mathrm{NO}_{\mathrm{x}}$ in the exhaust gases. There are many commercial available $\mathrm{NO}_{\mathrm{x}}$ emission reduction technologies in the market. The most widely used are: 
Table 8 - Current NOx reduction technologies

\begin{tabular}{|c|c|c|}
\hline Technology & Means & $\mathrm{NO}_{\mathrm{x}}$ reduction \\
\hline Selective Catalytic Reduction (SCR) & $\begin{array}{l}\text { Converts, with the aid of a catalyst, } \mathrm{NO}_{x} \text { in } \\
\text { to } \mathrm{N} 2 \text { and Water. }\end{array}$ & $50-95 \% *$ \\
\hline Lean Burn LNG engines & $\begin{array}{l}\text { LNG gives a much cleaner exhaust and is } \\
\text { the only technology that results in an } \\
\text { emission reduction for all major emission } \\
\text { components. }\end{array}$ & $80-90 \%$ \\
\hline Exhaust Gas Recirculation (EGR) & $\begin{array}{l}\text { EGR's work by recirculating a portion of an } \\
\text { engine's exhaust gas back to the engine } \\
\text { cylinders. This reduces the combustion } \\
\text { chamber temperature and thus the } \mathrm{NO}_{\mathrm{x}} \\
\text { generation is reduced. }\end{array}$ & $35-40 \% *$ \\
\hline Water Emulsion & $\begin{array}{l}\text { Fuel is mixed with an emulsifier and then } \\
\text { the emulsion is mixed with water. This } \\
\text { lowers the temperature in the combustion } \\
\text { chamber and hence the } \mathrm{NO}_{x} \text { generation is } \\
\text { reduced. }\end{array}$ & $10-50 \% *$ \\
\hline Humid Air Motor (HAM) & $\begin{array}{l}\text { HAM engines uses water injection in the air } \\
\text { intake to lower the combustion tempera- } \\
\text { ture and the } \mathrm{NO}_{x} \text { generation like for water } \\
\text { emulsion. }\end{array}$ & $10-60 \% *$ \\
\hline Engine re-build & $\begin{array}{l}\text { Adapt and optimize the engine wrt to } \mathrm{NO}_{x} \\
\text { emission. }\end{array}$ & $20-40 \% *$ \\
\hline
\end{tabular}

*Based on measured in-operation figures collected by the Norwegian $\mathrm{NO}_{\mathrm{x}}$ Found.

When operating in a $\mathrm{NO}_{\mathrm{x}} \mathrm{ECA}$ area, engines built after 2016 will have to comply with the Tier III requirements shown in Table 11 . This will put a lot of strain on the machinery manufacturers. Currently only three technologies are capable of achieving the required $\mathrm{NO}_{\mathrm{x}}$ reduction according to the Tier III requirements:

- LNG (lean burn) engines.

- Selective Catalytic Reduction (SCR).

- Exhaust Gas Recirculation (EGR) - possibly in cooperation with other $\mathrm{NO}_{\mathrm{x}}$ reduction measures.

\subsection{Particulate matter (PM)}

\subsubsection{PM and effects on health and the environment}

Particulate matter (PM) is the general term used for a mixture of aerosol particles (solid and liquid) with a wide range in size and chemical composition. PM2.5 refers to "fine particles" that have a diameter of $2.5 \mathrm{mi}$ crometres or less. PM10 refers to the particles with a diameter of 10 micrometres or less. PM10 includes the "coarse particles" fraction in addition to the PM2.5 fraction. 
Fuel quality, engine type (combustion conditions) and vessel activity play major roles in the property and variability of emissions. An improved understanding of emissions and processing of particles from a cross section of marine fuel types, diesel engine types and ship activity is essential to improve understanding of ship PM characteristics in the atmosphere, and the impact of shipping emissions on health, visibility and climate.

The primary reason for the impact of shipping emissions to health is because $70 \%$ of shipping occurs within $400 \mathrm{~km}$ of land and major shipping ports are located in areas surrounded by large populations.

$\mathrm{PM}$ is the least understood emission component from shipping and further work for obtaining improved emission factors is essential. An increased use of distillate fuels (as will be expected with the ECA implementation) will reduce the problem, but the relation to fuel quality is far from linear, nor fully understood.

Figure 8 - Reduction in life expectancy due to particle emission $\left(P M_{2,5}\right)$ in Europe in 2000 and 2020 [ref $/ 1 /]$
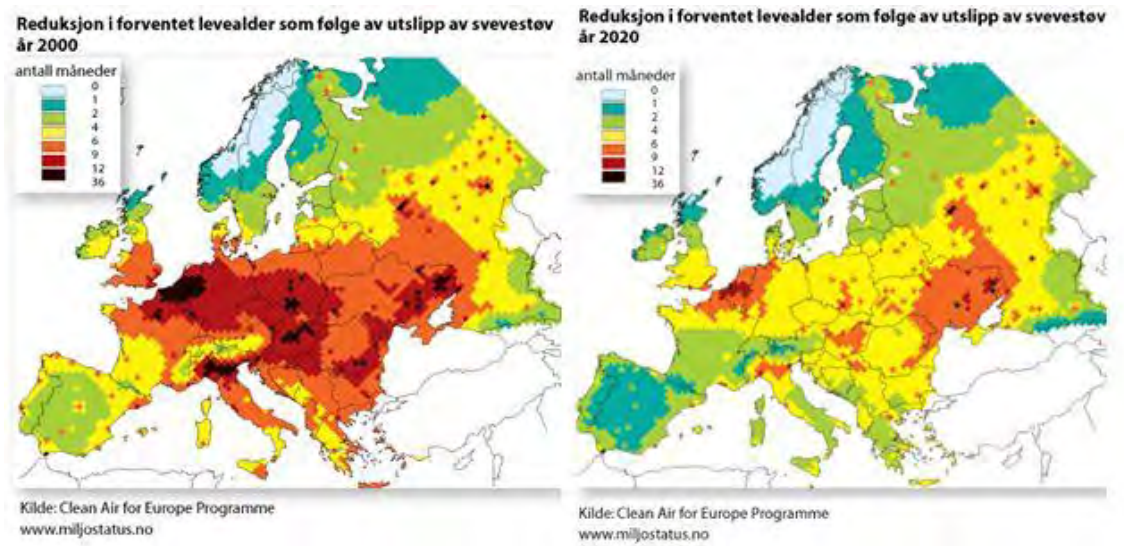

\subsubsection{PM reduction technologies}

For road engines a series of filter solutions have been developed, providing more than $90 \%$ reduction in PM emissions. These filters may also be tuned to reduce around $90 \%$ of $\mathrm{CO}$ and $\mathrm{HC}$ emission from diesel engines. For maritime engines such filters have not proven to be practicable due to the large amount of ash emission from the fuel and lubrication oil, and a consequent clogging of the filters. However, the development is ongoing and tests have indicated reduction potentials in the $60-80 \%$ region. This is counterbalanced by a small penalty on energy consumption due to increased back-pressure from the filters. 
Table 9 - PM emission reduction measures

\begin{tabular}{lll}
\hline Technology & Means & PM reduction \\
\hline PM filters & $\begin{array}{l}\text { Physical filtration of the exhaust gas with the added penalty } \\
\text { of increased back pressure and fuel consumption. }\end{array}$ & Potentially up to $85 \%$ \\
Scrubber & $\begin{array}{l}\text { Washes out the exhaust gas with water and reduces } \\
\text { the emission of both } \mathrm{SO}_{x} \text { and PM. }\end{array}$ & $40-75 \%$ \\
\hline
\end{tabular}

\section{3 $\mathrm{SO}_{\mathrm{x}}$ emissions}

The formation of sulphur oxides $\left(\mathrm{SO}_{\mathrm{x}}\right)$ in exhaust gases is caused by the oxidation of sulphur in fuel into $\mathrm{SO}_{2}$ and $\mathrm{SO}_{3}$ during the combustion process. The amount of $\mathrm{SO}_{\mathrm{x}}$ formed is a function of the sulphur content in the fuel used and therefore an effective method of reducing $\mathrm{SO}_{\mathrm{x}}$ is by reducing the sulphur content in the fuel. Unfortunately, low-sulphur fuels are more expensive to purchase (10 to $20 \%$ greater cost, when switching from $3.5 \%$ to $1 \%$ sulphur) and there is a practical lower sulphur limit as desulphurisation of fuel lowers the lubricity which can lead to increased wear on fuel pumps and injectors. The regulation of $\mathrm{SO}_{\mathrm{x}}$ is predominately a regional issue. However, international pressure is growing for the oil producers to reduce the sulphur content of all fuels in order to control this problem at the source.

\subsubsection{SO $\mathrm{S}_{x}$ and effects on health and the environment}

Both $\mathrm{SO}_{2}$ in its untransformed state, and the acid and sulphate transformation products of $\mathrm{SO}_{2}$, can have adverse effects on human health or the environment. $\mathrm{SO}_{2}$ itself can cause adverse effects on respiratory systems of humans and animals, and damage to vegetation. When dissolved by water vapour to form acids it can again have adverse effects on the respiratory systems of humans and animals, and it can cause damage to vegetation, buildings and materials, and contribute to acidification of aquatic and terrestrial ecosystems. 


\subsection{2 $S \mathrm{SO}_{\mathrm{x}}$ reduction technologies}

$\mathrm{SO}_{2}$ emissions are generated from the sulphur present in fuel and the emissions depend on the sulphur content of the fuel used. However, IMO MARPOL Annex VI opens up for alternatives to low sulphur fuel if similar performance may be documented.

Table $10-\mathrm{SO}_{\mathrm{x}}$ reduction measures and their effect

\begin{tabular}{llc}
\hline Technology & Means & SO $_{\mathbf{x}}$ reduction \\
\hline Scrubber & $\begin{array}{l}\text { Use liquid to wash unwanted pollutants from a gas stream. Current scrubbers will } \\
\text { make it possible to operate on traditional HFO and still meet the SECA requirements. }\end{array}$ & $\approx 98 \%$ \\
LNG & $\begin{array}{l}\text { Replace traditional fuel with natural gas, either with specialized LNG engines or dual- } \\
\text { fuel engines. }\end{array}$ & $95-100 \%$ \\
Distillate fuel & $\begin{array}{l}\text { Distillate fuel with reduces sulphur content (in SECA after 2015 it should be less than } \\
0.1 \%)\end{array}$ & $\approx 90 \%$ in SECA \\
& & \\
\hline
\end{tabular}




\section{Main regulatory regimes}

Modern shipping operates under a complex set of international and domestic regulations. Traditionally, the leaps in regulations have been eventdriven, and in some cases even driven by events outside the sector. Well known examples are the Titanic disaster, which ultimately led to the International Convention for the Safety of Life at Sea (SOLAS) Convention, the Exxon Valdez oil spill, which resulted in the Oil Pollution Act (OPA 90), and the 9/11 attack, which resulted in the International Ship and Port Facility Security (ISPS) Code. However, the environmental regulations have generally lagged behind those of other industries. This situation is now changing. The increased focus on both global and local environmental issues in general, combined with the growing realisation of the actual pollution burden imposed by shipping, has led to an upsurge in both international and national regulations. Some are ready and will enter into force in the very near future, while others are still being developed and will have an impact only in the intermediate term, [Ref /5/].

The key issues that will have a significant regulatory impact this decade are, broadly speaking, sulphur oxides $\left(\mathrm{SO}_{\mathrm{x}}\right)$, nitrous oxides $\left(\mathrm{NO}_{\mathrm{x}}\right)$ and particles (PM) in addition to Green House Gases (GHG).

Figure 9 - The maritime regulatory system showing the role of the 166 maritime states

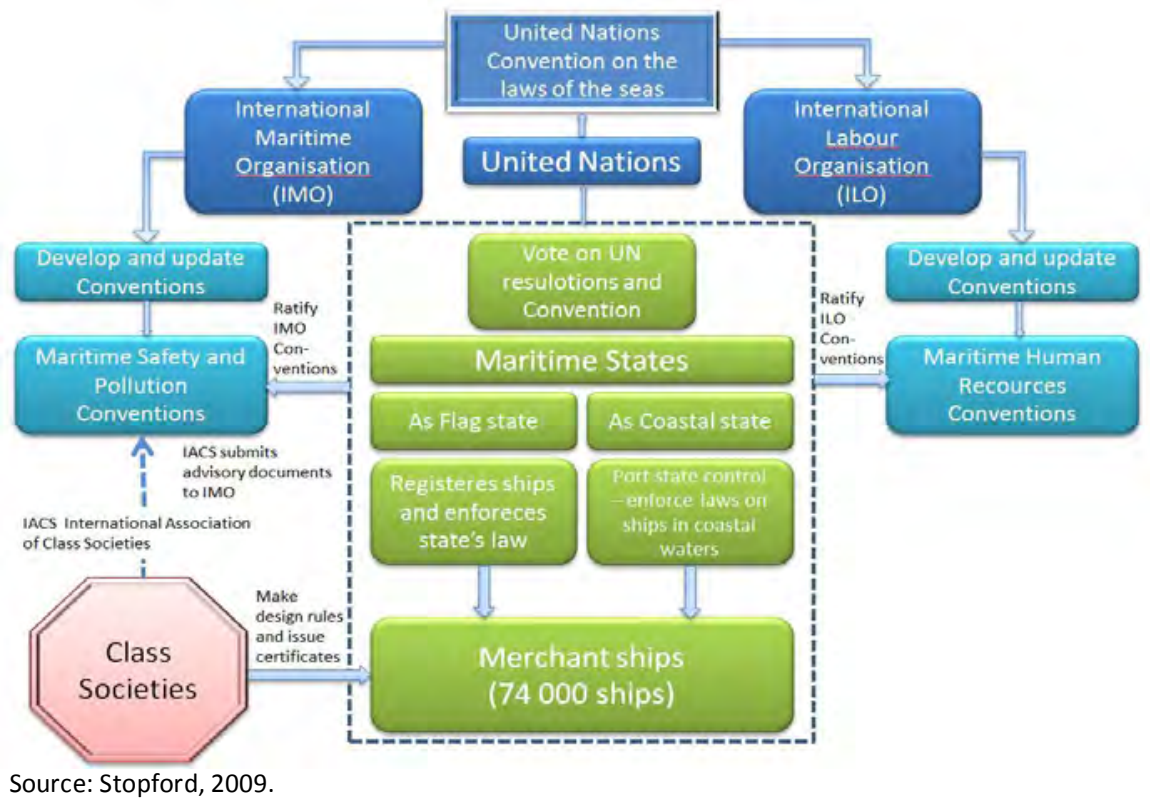




\subsection{UN Convention on the Law of the Sea}

As shown in Figure 9 the UN Convention on the Law of the Sea (UNCLOS) provides a universal legal framework for the control of marine related resources and activities. Any state's sovereignty over the territorial sea is subject to this Convention and to other rules of international law. Regulations on emissions to air have to be in line with UNCLOS.

A prerequisite to the Convention is that coastal states should not hamper the innocent passage of foreign ships through territorial seas except in accordance with the Convention. On the other hand, Article 21 permits states to "establish particular requirements for the prevention, reduction and control of pollution of the marine environment as a condition for the entry of foreign vessels into their ports". This is clearly defined in the Article 21 "Laws and regulations of the coastal State relating to innocent passage". This article states that coastal states may adopt laws and regulations for the preservation of the environment of the coastal State and the prevention, reduction and control of pollution. In short, coastal states may implement individual laws and regulations for the preservation of the environment. Note that this is not an option for straits such as Öresund. In general, for ships in innocent passage, national regulations will not apply. A vessel is only subject to such regulations when it is calling one of the nation's ports. Hence, for the individual coastal states there are no legal means of regulating international traffic only passing through Nordic waters.

\subsection{The International Convention of the Prevention of Pollution from Ships (MARPOL)}

The International Convention for the Prevention of Pollution from Ships (MARPOL) is the main IMO Convention regulating emissions to air from shipping. MARPOL was designed to minimize pollution of the seas, including dumping, oil and exhaust pollution. Its stated object is to preserve the marine environment through the complete elimination of pollution by oil and other harmful substances and the minimization of accidental discharge of such substances. All ships flagged under countries that are signatories to MARPOL are subject to its requirements, regardless of where they sail and member nations are responsible for vessels registered under their respective nationalities.

The Convention is split into six annexes concerned with preventing different forms of marine pollution from ships. Annex VI of MARPOL regulates emissions to air from marine engines. In general, Annex VI applies to all ships $400 \mathrm{GT}$ and above, and to all fixed and floating drilling rigs and other platforms. 
The revised Annex VI will over the coming years introduce requirements for a considerable reduction of air pollution from ships, especially in relation to $\mathrm{SO}_{\mathrm{x}}$ and $\mathrm{NO}_{\mathrm{x}}$ and in particular in the areas defined as ECA.

\subsection{1 $\mathrm{NO}_{\mathrm{x}}$ emission regulation}

In 2007, ministers of the HELCOM (HELsinki COMission) countries adopted the HELCOM Baltic Sea Action Plan to reach "Good Environmental Status" of the Baltic Sea by 2021. The aim of the action plan is to radically reduce pollution to the Baltic Sea and reverse its marine environmental degradation. This plan contains actions for restoration and protection of the marine environment of the Baltic Sea within four thematic areas: eutrophication, hazardous substances, biodiversity and maritime safety.

Shipping is the second largest contributor (9\%) to the deposition to air of nitrogen oxide, and the fifth greatest contributor (5\%) to the total atmospheric nitrogen deposition to the Baltic Sea, [REF /2/]. At the 33rd meeting of HELCOM it was decided to issue an IMO NECA application for the region and the application is completed.

Table $11-\mathrm{NO}_{\mathrm{x}}$ limits as a Tier I, II and III regieme as per IMO MARPOL

\begin{tabular}{lcrrr}
\hline Tier & Year & \multicolumn{2}{c}{ NO limit $[\mathbf{g} / \mathbf{k W h}]$} & \\
& & $\mathbf{n}<\mathbf{1 3 0}$ & $\mathbf{1 3 0} \leq \mathbf{n}<\mathbf{2 , 0 0 0}$ & $\mathbf{n} \geq \mathbf{2 , 0 0 0}$ \\
\hline Tier I & 2000 & 17.0 & $45 \times \mathrm{n}^{-0.2}$ & 9.8 \\
Tier II & $2011 *$ & 14.4 & $44 \times \mathrm{n}^{-0.23}$ & 7.7 \\
Tier III* & $2016^{*}$ & 3.4 & $9 \times \mathrm{n}^{-0.2}$ & 1.96 \\
\hline
\end{tabular}

*Applies to $\mathrm{NO}_{\mathrm{x}}$ Emission Control Areas only.

Tier I (global): becomes applicable to existing engines installed on ships built between 1990 and 2000 with a displacement $\geq 90$ litres per cylinder and rated output $\geq 5,000 \mathrm{~kW}$.

Tier II (global): Could be met by engine modification packages (EMP) or low $\mathrm{NO}_{\mathrm{x}}$ engines for new engines.

Tier III (NO $\mathrm{NCAs}_{\mathrm{S}}$ : Need additional post treatment (e.g. SCR) or LNG.

Figure 10 - Allowable $\mathrm{NO}_{x}$ emission Tier limits against engine speed

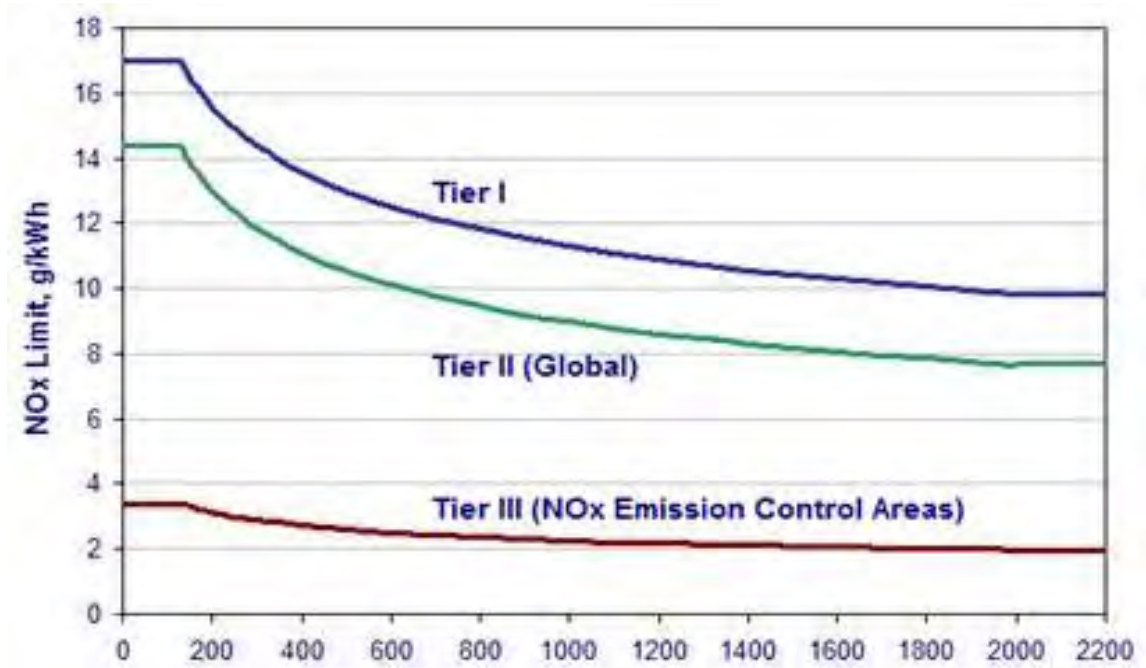


Currently all new buildings will need to have machinery compliant with the Tier II requirements. Representing a 74\% reduction in $\mathrm{NO}_{\mathrm{x}}$ emissions compared to the Tier II levels, the IMO Tier III requirement goes into effect in January 2016 in a $\mathrm{NO}_{\mathrm{x}}$ ECA area. Tier III poses significant challenges to engine developers, who will need to cut $\mathrm{NO}_{\mathrm{x}}$ emissions to Tier III levels or apply $\mathrm{NO}_{\mathrm{x}}$ measures with the help of other engine technologies.

Figure 11 shows how the different $\mathrm{NO}_{\mathrm{x}}$ abatement technologies are able to meet the new Tier III requirements. The figure is based on the measured operational abatement efficiency of 53 installed and verified SCR-systems and is collected by DNV as technical advisors for the $\mathrm{NO}_{\mathrm{x}}$ found. As shown, about $60 \%$ of the installed SCRs do not meet the Tier III requirements due to their high operational $\mathrm{NO}_{\mathrm{x}}$ factors. The tier limits are plotted at $750 \mathrm{rpm}$, which forms the most representative engine speed among the measures.

Figure 11 - Ability to meet IMO Tier III emission limits - measured values from the Norwegian $\mathrm{NO}_{x}$ found

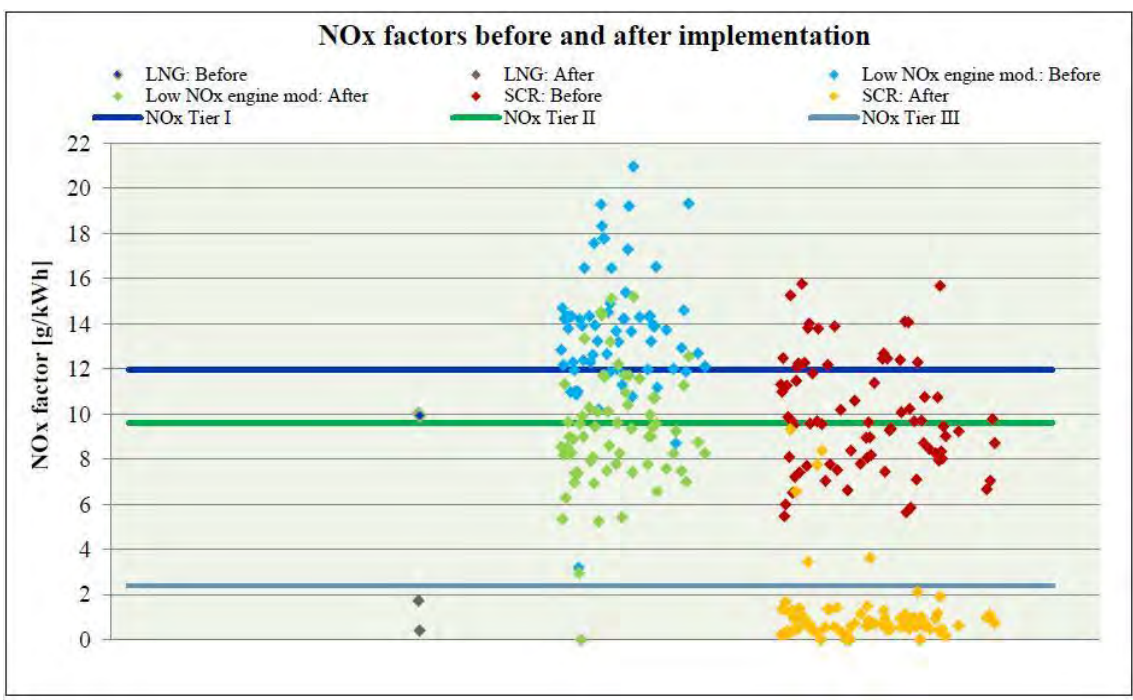

Whereas the effect of the $\mathrm{SO}_{\mathrm{x}} \mathrm{ECA}$ implementation will be instantaneous as a result of fuel swich or abatement technologies, the $\mathrm{NO}_{\mathrm{x}}$ ECA requirements will gradually take effect over the next 30 years. The Tier III requirements will only be fully effective when all Tier I and II vessels are phased out. The effect is illustrated in Figure 12 and Figure 13. 
Figure $12-\mathrm{NO}_{\mathrm{x}}$ emission to the Baltic Sea with - or without the introduction of a $\mathrm{NO}_{x}$ ECA [Ref /9/]

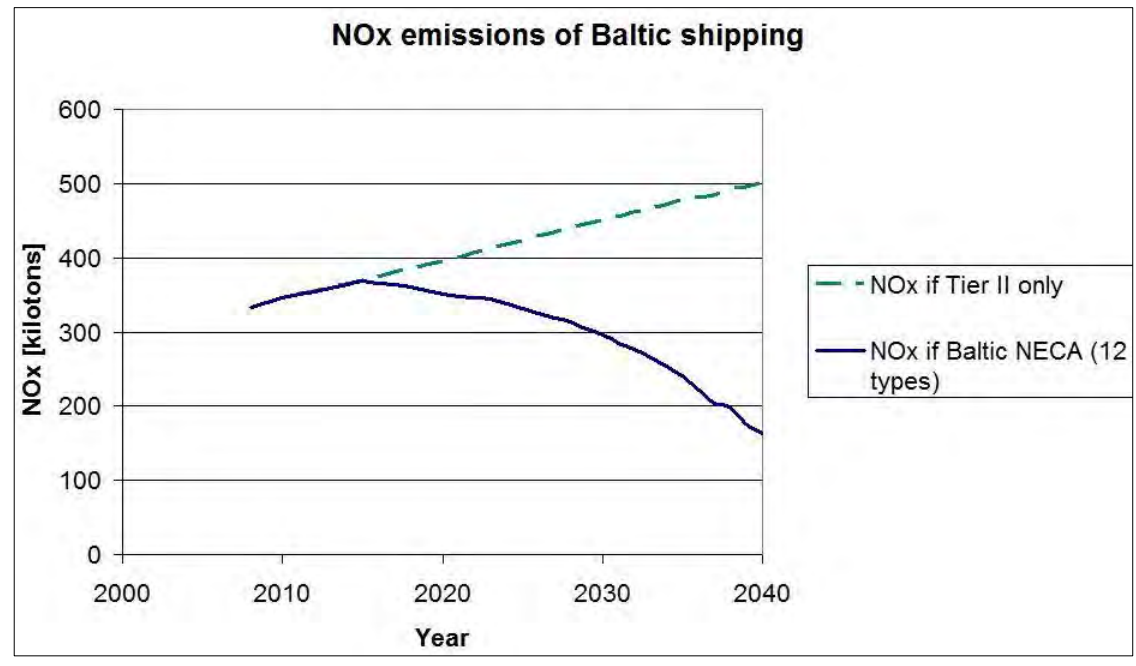

Figure $13-\mathrm{NO}_{\mathrm{x}}$ emission from shipping in the Baltic Sea-assuming $\mathrm{NO}_{\mathrm{x}} \mathrm{ECA}$ [Ref $/ 9 /]$

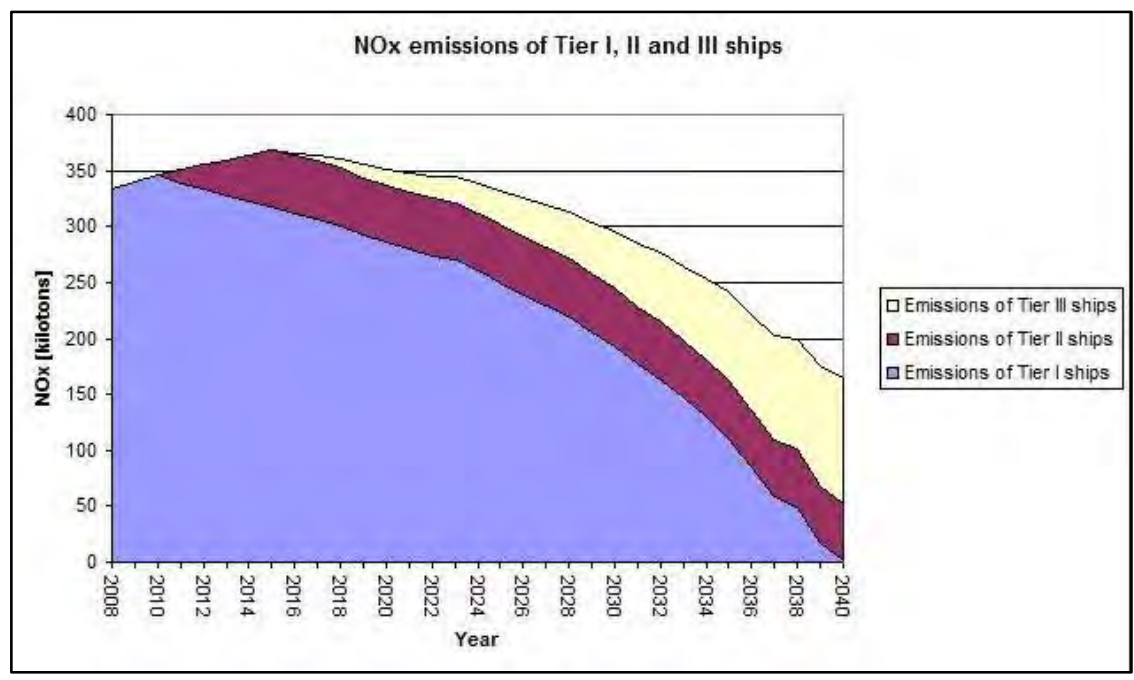


Figure 14 - The potential reduction to human exposure of $\mathrm{NO}_{x}$ in 2040 by introducing a $\mathrm{NO}_{x}$ ECA in the Baltic Sea. (Before $\mathrm{NO}_{x}$ ECA Tier II will apply. With $\mathrm{NO}_{x}$ ECA Tier III will apply to engines built after 2016)

Tier II vs Tier III (\%) 드ำ
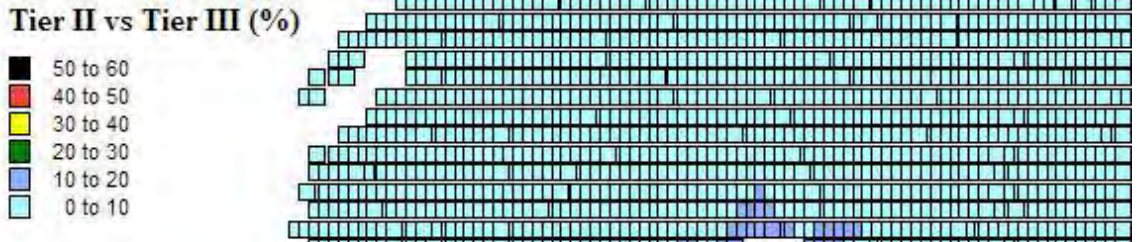

0 to 10

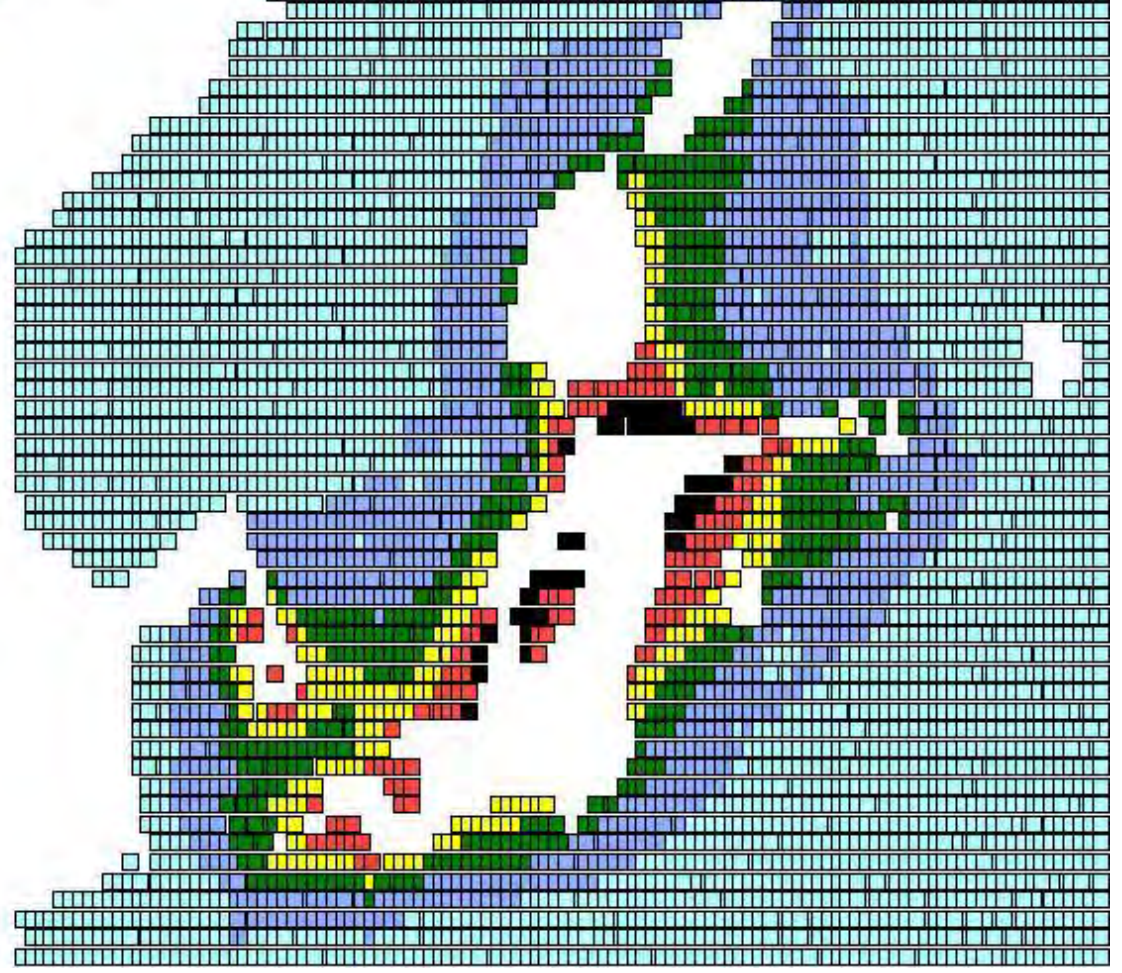

\subsection{2 $\mathrm{SO}_{\mathrm{x}}$ emission regulation}

Figure 15 - Implementation plan for Global and SECA fuel sulphur limit

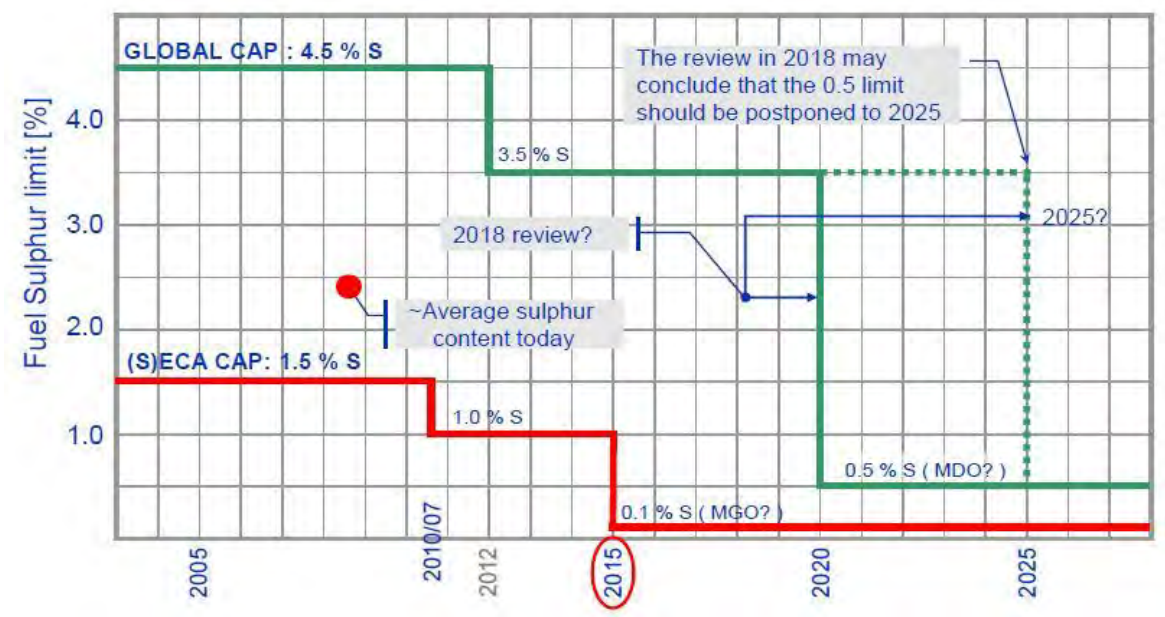


In the revised MARPOL Annex VI, IMO introduces limits to how much sulphur vessels are allowed to emit. MARPOL Annex VI allows vessels to comply with the regulations in different ways. Either by using fuel oil with a sulphur content below a prescribed limit or by utilising a "fitting, material, appliance or apparatus". This may be exhaust gas cleaning technology, or by "other procedures such as on-board blending of fuel oil or the use of dual fuel (gas/liquid). When an alternative means of compliance is used it must be "at least as effective in terms of emission reductions as that required by this Annex". Any alternative means of compliance with the regulations must be approved by the vessel's Flag Administration.

Shipping in the Baltic emits twice as much $\mathrm{SO}_{2}$ as Denmark and Sweden combined. This initiated the states bordering the Baltic Sea to become the world's first $\mathrm{SO}_{\mathrm{x}}$ ECA. The North Sea followed next in 2005. This means that vessels are not allowed to emit more $\mathrm{SO}_{\mathrm{x}}$ equivalent to a vessel using $1 \%$ sulphur fuel within these areas (see Figure 16). Within 1 January 2015 no vessel is allowed to emit more $\mathrm{SO}_{\mathrm{x}}$ than a vessel using fuel with $0.1 \%$ sulphur. Hence, from 2015 all vessels in the Baltic and the North Sea will be regulated as strict as practically possible with respect to $\mathrm{SO}_{\mathrm{x}}$ emission and further regulations are likely to be costly and of limited value. Hence, this project will not consider any additional regulations on $\mathrm{SO}_{\mathrm{x}}$ emissions within the current ECA area.

Figure 16 - The current $S_{x}$ ECA area in the Baltic and North Sea

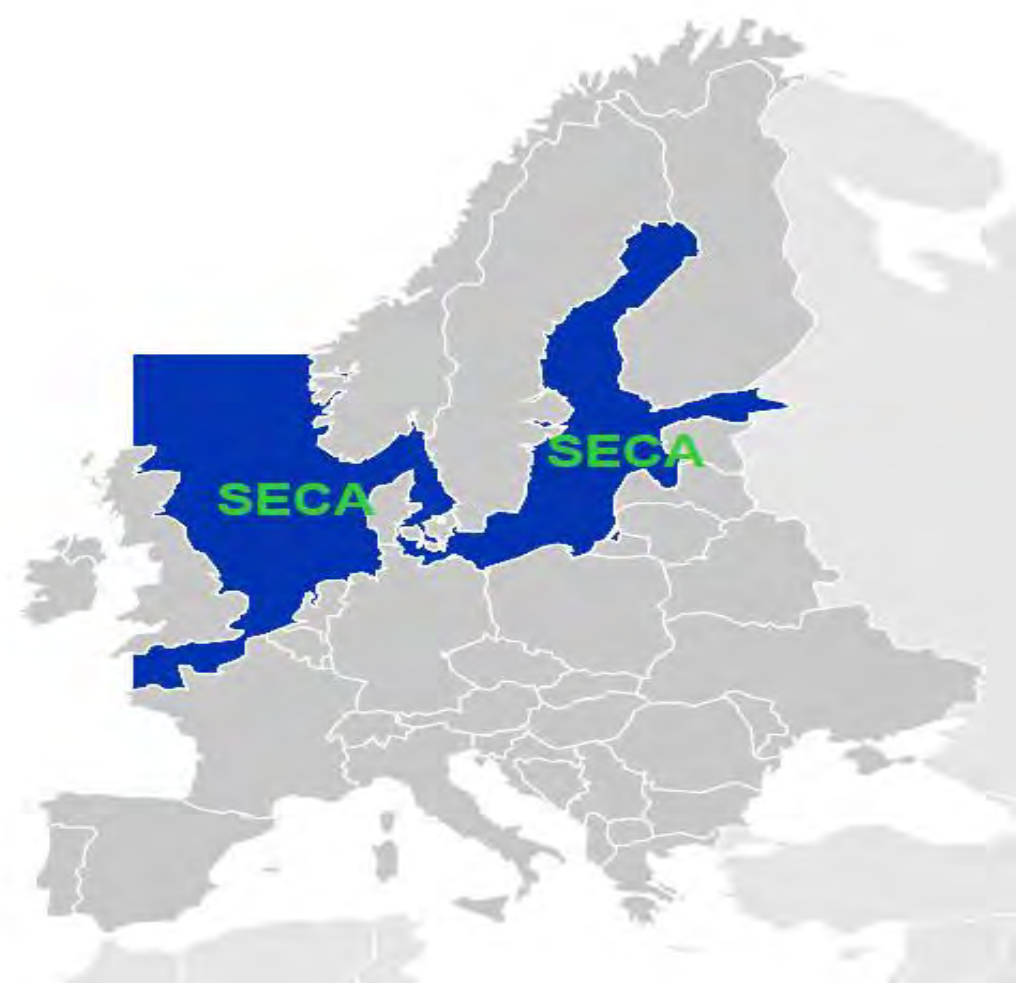




\subsection{The EU Air Quality Directive}

The aim of the EU Directive is to reduce health and environmental effects from air pollution from non-road mobile equipment. The Directive offers options for Member States to set stricter emission limits in special areas of inland waterways.

\subsubsection{The EU Sulphur Directive}

The EU Sulphur Directive (2005/33/EC) sets limits on the maximum sulphur content of gas oils and heavy fuel oil in land-based applications as well as marine fuels. In doing so, the Directive incorporates the sulphur provisions of the MARPOL Annex VI.

Article $4 \mathrm{~b}$ of the Directive requires that, with effect from 1 January 2010, Member States must take all necessary steps to ensure that ships berthed or anchored in European Community ports are not permitted to consume marine fuels with a sulphur content exceeding $0.1 \%$ by mass. This regulation applies to all vessels irrespective of flag, ship type, age or tonnage. In practice this means that many ships must switch from residual fuel oil (heavy fuel oil) to distillate fuel, such as marine gas oil, when in port. The Directive requires that this fuel change-over operation should be carried out as soon as possible after arrival and as late as possible prior to sailing. Current EU limits:

- $1.0 \%$ sulphur limit in IMO $\mathrm{SO}_{\mathrm{x}}$ ECA's (from July 2010). This includes the Baltic Sea, North Sea and the English Channel.

- $1.5 \%$ sulphur limit for passenger vessels in EU waters.

- $0.1 \%$ sulphur limit for any fuel used on-board ships in EU ports as of 1 January 2010.

- All sulphur limits are aligned with those in MARPOL Annex VI, however, 2020 has been set as the final date for the $0.5 \%$ limit to enter into force (without the 2018 IMO review).

- Passenger ships on regular services will continue to apply $1.5 \%$ until 2020 when the $0.5 \%$ global limit will come into force.

- Included in a recital - the Commission should by 2013 look into the impact of a $0.1 \%$ limit in all EU territorial waters i.e. a sort of "review clause" pushed by the EP and to be done in the context of the EU's 2013 air quality review.

- State aid can be granted to subsidise scrubbers.

- A cap on 3.5\% sulphur in fuel has been set except for the use in conjunction with closed loop scrubbers.

A recent study reveals that levels of sulphur dioxide in EU ports have been reduced by $66 \%$ as a result of the EU Directive 1999/32/EC which required low-sulphur fuels for ships at berth or at anchor in ports (European Commissions Joint Research Centre (JRC). 


\subsection{The 1999 Protocol to Abate Acidification, Eutrophication and Ground-level Ozone (The Gothenburg Protocol)}

The Gothenburg protocol (GP) was adopted on 30 November 1999 and entered into force on 17 May 2005.

The objective of the 1999 Protocol is to control and reduce emissions of sulphur, nitrogen oxides, ammonia and volatile organic compounds that are caused by anthropogenic activities and are likely to cause adverse effects on human health, natural ecosystems, materials and crops, due to acidification, eutrophication or ground-level ozone as a result of long-range transboundary atmospheric transport. Once the Protocol is fully implemented, Europe's sulphur emissions should be cut by at least $63 \%$, its $\mathrm{NO}_{\mathrm{x}}$ emissions by $41 \%$, its VOC emissions by $40 \%$ and its ammonia emissions by $17 \%$ compared to 1990 .

Each Party is having an emission ceiling and shall reduce and maintain the reduction in its annual emissions in accordance with that ceiling and the timescales specified in that annex. Each Party shall, as a minimum, control its annual emissions of polluting compounds in accordance with the obligations in annex II.

A revised GT was agreed upon in May 2012 and it concluded that in addition to a ceiling on emissions according to 2010 levels new levels for 2020 were also agreed.

\section{5 $\mathrm{NO}_{\mathrm{x}}$ fund in Norway (until 2017)}

The Business Sector's $\mathrm{NO}_{\mathrm{x}}$ Fund was initiated after the introduction of the Norwegian tax on $\mathrm{NO}_{\mathrm{x}}$ emissions in 2007. To date, the $\mathrm{NO}_{\mathrm{x}}$ Fund has granted more than $€ 300$ million in investment support to verifiable $\mathrm{NO}_{\mathrm{x}}$ reduction abatement initiatives on ships operating in Norwegian waters. Det Norske Veritas (DNV) acts as a technical advisor for this regime. Since 2008, DNV has overseen more than 750 applications for investment support for $\mathrm{NO}_{\mathrm{x}}$ reduction measures and has validated several hundred investment cases to reduce ship specific $\mathrm{NO}_{\mathrm{x}}$ emissions or to lower fuel consumption. More than 300 of these measures have now been installed and the achieved $\mathrm{NO}_{\mathrm{x}}$ reduction has been validated. The Fund has about $€ 80$ million each year available for support of $\mathrm{NO}_{\mathrm{x}}$ reducing measures.

As shown in Figure 17 Selective Catalyst Reduction (SCR) systems, LNG as fuel, low $\mathrm{NO}_{\mathrm{x}}$ engine tuning, humidity or emulsion systems, exhaust gas recirculation and various fuel saving measures are among the typical abatement initiatives granted support. 
All ships that pay a $\mathrm{NO}_{\mathrm{x}}$ tax to the Fund are eligible for financial support. The degree of support for a specific measure depends on three parameters:

- Type of $\mathrm{NO}_{\mathrm{x}}$ reducing measure.

- Quantity of $\mathrm{NO}_{\mathrm{x}}$ reduction (kg per year).

- Implementation cost.

Affiliated enterprises are entitled to exemption from fiscal $\mathrm{NO}_{\mathrm{x}}$ tax of $€$ 2.05 per $\mathrm{kg} \mathrm{NO}_{\mathrm{x}}$ and pay lower rates into the fund.

- The shipping industry etc. pays $€ 0.5$ per $\mathrm{kg} \mathrm{NO}_{\mathrm{x}}$.

- Oil and gas production $€ 1.3$ per $\mathrm{kg} \mathrm{NO}_{\mathrm{x}}$.

- 644 affiliated enterprises by 14 November 2011.

- The Fund has about $€ 80$ million each year available for support of $\mathrm{NO}_{\mathrm{x}}$ reducing measures.

From the start in 2008 most applications for support regarded SCR (with the use of urea) and low- $\mathrm{NO}_{\mathrm{x}}$ engine modifications. Owners of fishing vessels and offshore service ships were early to implement such measures. In 2011 the $\mathrm{NO}_{\mathrm{x}}$ Fund Agreement was extended to 2017. Now the Fund is experiencing an increasing trend of applications for LNG fuelled ships, representing almost $50 \%$ of the $\mathrm{NO}_{\mathrm{x}}$ reduction (tonnes) for applications received after 1.1.2011. Up to this date, the $\mathrm{NO}_{\mathrm{x}}$ Fund has granted support to almost $50 \mathrm{LNG}$ fuelled ships and the number is expected to increase in the future.

Figure 17 - Actual measured reduction from the different measures supported by the $\mathrm{NO}_{x}$ found

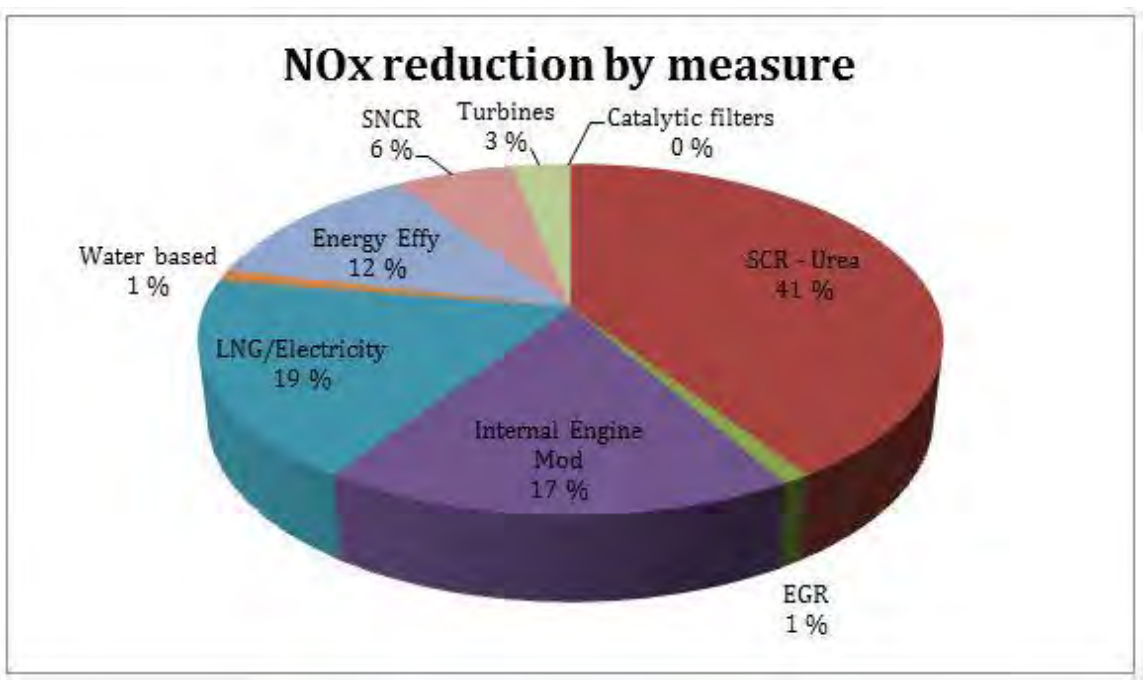


Figure 18 - Measured actual $\mathrm{NO}_{x}$ reductions and verified actual investment costs for $\mathrm{NO}_{x}$ abatement technologies

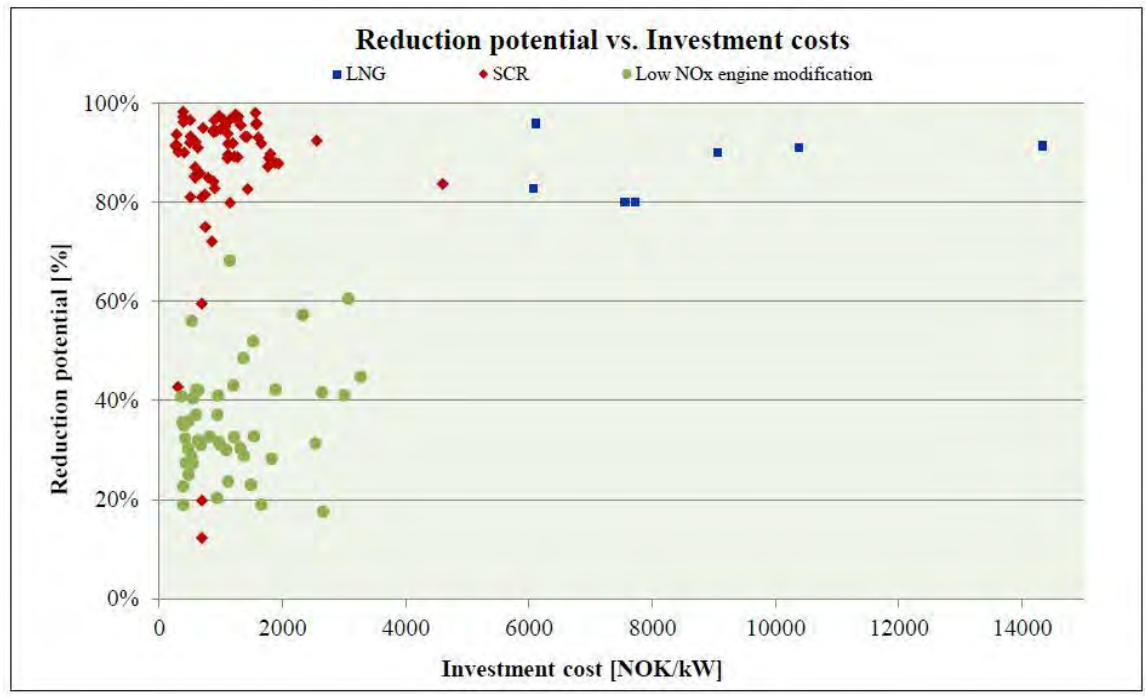

Total verified $\mathrm{NO}_{\mathrm{x}}$ reductions from ships in Norwegian waters that have successfully installed measures supported by the fund amounts to about 19,000 tons per year and are in line with the expectations in the Agreement. A larger number of ships have been granted support, but have not yet installed the reduction measures. By 2017 an additional 16,000 tons yearly reduction is expected to be initiated. Financial support from the $\mathrm{NO}_{\mathrm{x}}$ Fund has initiated emission reduction measures on ships in Norwegian waters to a larger extent than would be the case without such incentives. Further, $\mathrm{NO}_{\mathrm{x}}$ Fund support has stimulated the development of marine environmental technologies and verification regimes.

\subsection{Active public purchasing}

\subsubsection{Hordaland Fylkeskommune (Norway)}

The National and regional public sector in the Nordic countries are major investors in public transport and hence they are also in the position where they may influence the technology choice and even the technology development. In 2011 Hordaland Fylkeskommune [Ref/3/] on the west coast of Norway announced a pre-study addressing potential propulsion technologies for renewal of the 17 ferry routes in the district. The current fleet average age is 25 years and hence a renewal is called for.

An open scope approach was selected both for the choice of energy carrier and the propulsion technology and some quite radical solutions including battery/electric came out favourably. 


\section{7 "Farledsavgift" (Sweden)}

After a decision by the Swedish Government in February 2004, the Swedish Maritime Administration was assigned the task of developing a fairway dues system. The main purpose of the change was to increase the financial incentives for improving the environmental performance of vessels. This approach has been further strengthened with the tightening of environmental differentiation in the system that was implemented on 1 April 2008.

Fairway dues are in two parts where one part is based on the vessel's gross tonnage and the second part on loaded and unloaded cargo. For domestic freights the tax is goods-based only.

Vessels operating solely on bunker fuel with a sulphur content not exceeding $0.5 \%$ by weight are given a discount of SEK 0.50 on sulphur charges, which typically amounts to SEK 0.70 . Vessels operating solely on bunker fuel with a sulphur content of less than 0.2 weight- $\%$ sulphur are exempted from tax.

Vessels that have installed equipment to reduce nitrogen oxide emissions will receive a discount on the gross tonnage based fairway dues. This is given as a linear scale that starts at an emission level of $10 \mathrm{~g} /$ $\mathrm{kWh}$ and goes down to below $0.4 \mathrm{~g} / \mathrm{kWh}$ which vessels are exempt from gross tonnage-based fairway dues. 


\section{Potential Emission reduction measures in the Nordic region and conclusions}

This chapter discusses the most relevant measures to regulate $\mathrm{NO}_{\mathrm{x}}, \mathrm{SO}_{\mathrm{x}}$ and particulate emissions in Nordic waters, with an emphasis on $\mathrm{NO}_{\mathrm{x}}$.

\subsection{Overview}

Integrating international legislation in national legislation is one of the main options for Nordic states to regulate emissions from ships in Nordic waters. Although international legislation provides an option for national regulation of innocent passage for special environmental concerns, it is not common practice for a country to adopt special national regulations, especially for ships not calling a port within the region. This means that in practice the Nordic authorities can only regulate exhaust gas emissions from ships calling at Nordic ports.

According to Annex VI of MARPOL, tighter regulations may apply to certain areas (Emission Control Areas - ECAs). The revised Annex VI allows for waters to be designated as $\mathrm{SO}_{\mathrm{x}}$ or $\mathrm{NO}_{\mathrm{x}}$ ECAs, or as ECAs for all types of emissions from ships, if supported by a demonstrated need to prevent, reduce and control one or all emission factors from shipping.

IMO has already designated the Baltic Sea, the North Sea and the English Channel as $\mathrm{SO}_{\mathrm{x}}$ ECAs. The EU Sulphur directive already (from July 2010 ) imposes a ban of fuel with more than $1 \%$ sulphur and $0.1 \%$ in ports and inland waterways. Beyond this it is difficult to see how the $\mathrm{SO}_{\mathrm{x}}$ emission may be further reduced when the strictest requirements will come in to force in 2015. It is expected that the Baltic Sea and the North Sea will also be designated as $\mathrm{NO}_{\mathrm{x}}$ ECAs in the near future [Ref $\left./ 7 /\right]$. Hence, all vessels built after 2016 will have to comply with the strictest Tier III emission requirements for $\mathrm{NO}_{\mathrm{x}}$.

In addition to this, for all Nordic EU member nations the EU Sulphur Directive (2005/33/EC) sets limits to the maximum sulphur content of gas oils and heavy fuel oil in marine fuels with the most important limitation is the $0.1 \%$ sulphur cap on fuel used in EU ports. 
The fact that $\mathrm{SO}_{\mathrm{x}}$ is already regulated for most of the Nordic waters, and $\mathrm{NO}_{\mathrm{x}}$ - and possibly PM - are regulated for ships built after 2016, any further regulations will have to concentrate on the less regulated part of the fleet and areas.

- Existing vessels and the ones built up to 2016 will only have to comply with the Tier I and Tier II $\mathrm{NO}_{\mathrm{x}}$ emission requirements. As may be seen in Figure 10 Tier I and II are much less rigorous than the Tier III requirements. Hence, for the next 20-30 years the Tier I and Tier II vessels will still be dominating contributors to the $\mathrm{NO}_{\mathrm{x}}$ emission from shipping and the effect of this is clearly shown in Figure 12. Hence any additional regulations/actions should focus on this group of vessels and possibly single out particular vessel groups particularly suited for regulations. This could be due to a minimal risk of modal shifts (f.ex. that transport is moved to road due to the increase in cost imposed on sea transport) or the fact that the vessel category is a particularly important contributor to the $\mathrm{NO}_{\mathrm{x}}$ emissions.

- Vessels operating in non-ECA areas such as the Norwegian Sea and the Barents Sea, both with respect to $\mathrm{SO}_{\mathrm{x}}$ and $\mathrm{NO}_{\mathrm{x}}$.

\subsection{Regulative measures}

DNV see two main issues where Nordic regulator work may make a considerable impact on the emission to air from shipping.

\subsubsection{NO $\mathrm{NO}_{\mathrm{X}} \mathrm{ECA}$ in the Baltic and the North Sea}

The North Sea and the Baltic are already $\mathrm{SO}_{\mathrm{x}}$ ECA's and hence for these waters little may be done ensuring a further reduction of $\mathrm{SO}_{\mathrm{x}}$ emissions. The application for the Baltic regarding a future $\mathrm{NO}_{\mathrm{x}} \mathrm{ECA}$ is ready and is expected to be submitted soon. Further, the $\mathrm{NO}_{\mathrm{x}}$ ECA for the North Sea is yet to be finalised and no immediate agreement to apply seem to be landed. Hence the most important regulatory initiative for the Nordic is to provide support for these application processes to be running as smooth and rapid as possible.

\subsubsection{Regulating the ferry/passenger traffic}

It is also worth noting that the ferry/passenger industry is by far the largest contributor to $\mathrm{NO}_{\mathrm{x}}$ and particle emission in the region (as shown in Figure 5). Hence, looking for ways of accelerating the implementation of Tier III compliant vessels in this category will have major impacts on the total $\mathrm{NO}_{\mathrm{x}}$ emission. If all passenger vessels operating in Nordic waters were Tier III compliant, yearly reduction effects equivalent to 4-5 times the Norwegian $\mathrm{NO}_{\mathrm{x}}$ founds (Around 80,000 tonnes yearly) may be 
obtained. Hence, where licences for operation are required, actively stimulating for Tier III compliant vessels will potentially have a significant effect to the $\mathrm{NO}_{\mathrm{x}}$ emission in the area, and likely also for PM emissions. Note that the major contributors to the emissions in the passenger category are large passenger ferries operating between the Nordic countries. Hence the potential for regulating the traffic is more at hand than for the international traffic to and from destinations outside the Nordic.

\subsection{Stimulating measures}

\subsubsection{Application of the $\mathrm{NO}_{\mathrm{x}}$ found model}

In the Norwegian $\mathrm{NO}_{\mathrm{x}}$-fund model all members that pay a $\mathrm{NO}_{\mathrm{x}}$ tax to the Fund are eligible for financial support. The degree of support for a specific measure depends on three parameters:

- Type of $\mathrm{NO}_{\mathrm{x}}$ reducing measure.

- Quantity of $\mathrm{NO}_{\mathrm{x}}$ reduction (kg per year within Norwegian dutiable service).

- Implementation cost.

See Section 4.5 for further description of the model.

Note that the model is based on support for initiatives reducing emissions beyond existing emission requirements. Thus, for vessels that have keel laid/new machinery installed on or after 1.1.2016 and operating within ECAs, support from the fund is no more relevant as Tier III then represents the existing requirement (provided the $\mathrm{NO}_{\mathrm{x}}$ ECA is effectuated) which is largely equivalent to the emission reduction reached by the most effective measures applied for. Hence, an extended $\mathrm{NO}_{\mathrm{x}}$ Fund model would have to focus on vessels keel-laid prior to 2016 and consequently support measures on existing vessels such as engine refurbishments and rebuilds, fuel saving measures and retrofit of technologies such as SCR.

\subsubsection{Accelerated upgrade/renewal of an aging fleet}

As illustrated in Figure 12 for the Baltic Sea, the effects of a $\mathrm{NO}_{\mathrm{x}} \mathrm{ECA}$ introduction are slow to materialize due to the fact that the regulations apply to vessels keel laid from 2016 and onwards. Such regulations may even extend the lifetime of aging vessels due to the added cost of new buildings complying with the new and stricter regulations.

Looking at the age distribution of the fleet operation in Nordic waters today as shown in Table 4 it is clear that a large proportion is old. This is 
particularly the case for the smaller vessels which also are likely to operate mostly domestically or at least locally.

Hence, incentives for replacing aging vessels may be an important way of accelerating the effects of a new regulatory regime. One possibility is to introduce a system with incentives for ship scrapping and replacement, which could be implemented for a limited period. The purpose will be to encourage operators with older vessels to remove their ships from the fleet. Such a system may imply that the owner conducts a commercial scrapping of the ship, and that triggers compensation in the form of a payment from the government. The compensation could for example be $25 \%$ of the ship's commercial value by the time of scrapping.

The ultimate potential for reduction in $\mathrm{NO}_{\mathrm{x}}$ emission from shipping in Nordic waters is around 400,000 tonnes/year moving towards a fully implemented Tier III regime (assuming today's share of Tier III compliant engines is close to zero).

Figure 19 - Typical set-up for shore based cold ironing

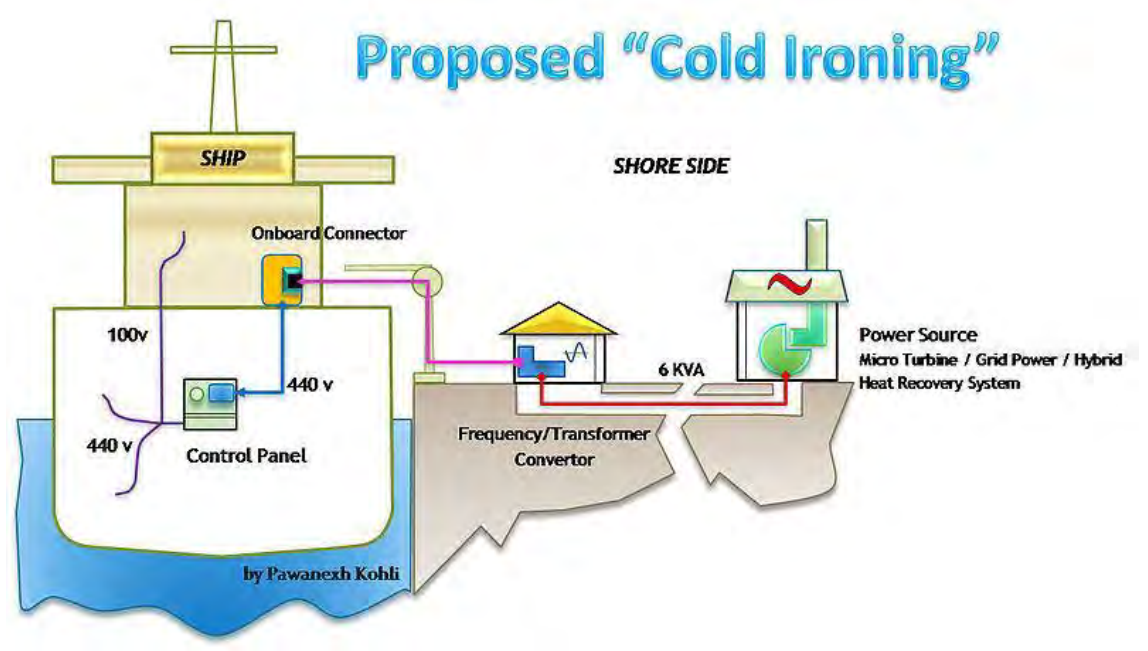

\subsubsection{Stimulation for Cold ironing in Nordic ports}

Cold Ironing, Alternative Maritime Power, shore power or shore supply is the process of providing shore side electrical power to a ship at berth while its main and auxiliary engines are turned off. Cold Ironing is not common on merchant ships as it involves switching off all its independent internal power sources when in harbour. For its operational requirements a power source from land is used.

Cold ironing does away with the need to burn fossil fuel on-board ships while they are docked. In this concept, ships visiting ports are hooked on to local grid power - or other - power sources which are already regulated by local pollution norms. This shore-sourced power 
serves the ship's cargo handling machinery and hoteling requirements. Effectively, all generating sources are shut down and the ship is hence cold-ironed. This brings immediate relief from pollution by shipboard emissions and allows a more holistic maintenance schedule to be followed by ship operators, which are typically hard put to maintain planned maintenance schedules due to commercial operating pressures.

\section{Challenges}

Ships, built in diverse international yards, have no uniform voltage and frequency requirement. Some ships use 220 volts at $50 \mathrm{~Hz}$, some at 60 $\mathrm{Hz}$, some others use 110 volts. Primary distribution voltage can vary from 440 volts to 11 kilovolts.

Load requirement varies from ship to ship and ranges from a few hundred $\mathrm{kW}$ in case of car carriers to a dozen or more MW in case of passenger ships or reefer ships.

Connectors and cables are not internationally standardised, though work has progressed in this direction. There are also other legal implications to outsourcing primary power source.

All these challenges are addressable and work has already begun in reducing ship emissions by cold ironing.

Power supply form the land grid can reduce $\mathrm{NO}_{\mathrm{x}}$ and other emissions from ships at berth, but the net effect depends on the sources for electricity production supplying the land grid. The potential gain from this option depends not only on power supply, but also on measures to standardize power sockets and current qualities.

\subsubsection{Initiatives for accelerating the establishment of LNG terminals}

The obstacles to the adoption of LNG as a marine fuel are practical factors, but they are not technical. The introduction of LNG as ship fuel is very much in a "chicken and the egg" situation. Owners are reluctant to invest in LNG fuelled vessels because of limited supply of LNG and the gas suppliers are hesitant to carry the considerable investments required for establishing a network of terminals before the customer base is more robust.

Establishing safe, reliable regional LNG bunkering capability is feasible. But it will require considerable investment and risk management, and it will have to cover significant operational costs to challenge existing fuel-oil delivery systems. The likelihood of regional LNG bunkering facilities being established will depend on high demand for LNG-fuel, which again will be driven by the price of LNG relative to current and future alternatives. 
Already several bunkering facilities are planned and as shown in Figure 20 the ones currently in use are situated in Norway. This is a direct result of the demand coming from the increasing LNG fleet stimulated by the Norwegian $\mathrm{NO}_{\mathrm{x}}$ found. Hence, stimulating to an implementation of LNG vessels through financial models or licence requirements will also stimulate the establishment of LNG terminals.

Figure 20 - Planned and implemented LNG terminals in Europe

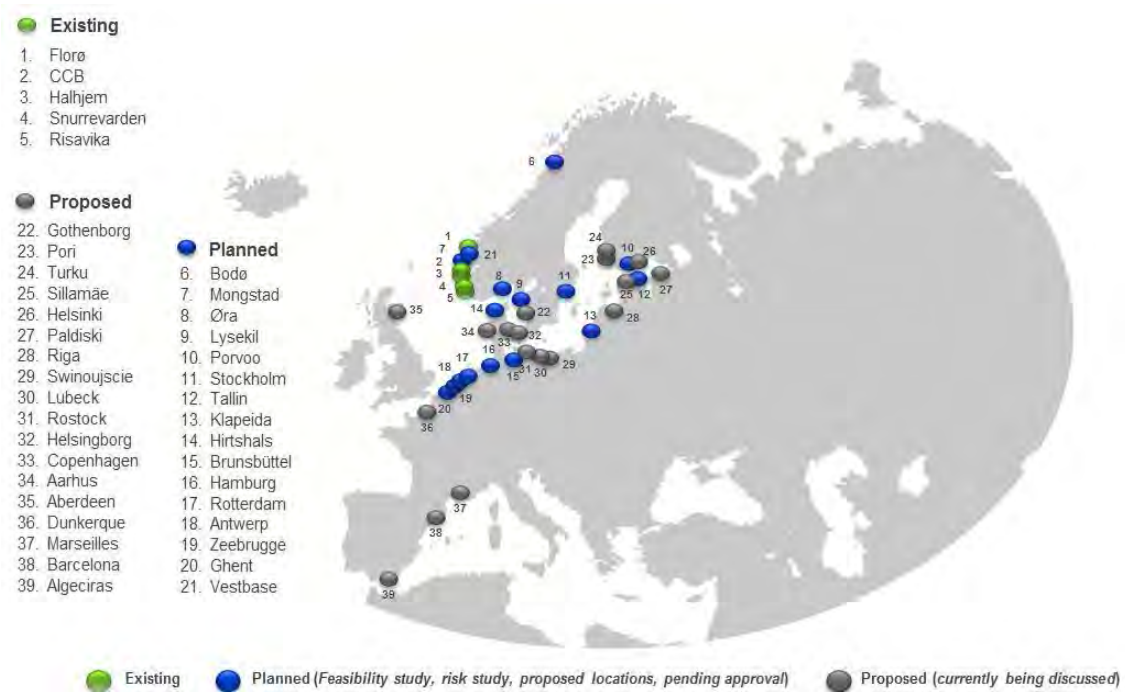

\subsection{Market-based measures}

\subsubsection{Differentiated port dues based on emission level}

A differentiated port due system could be designed as a fee bate system, that is a tax for ships that emit above a specific level, as well as a rebate for ships that emit less than this level [Ref /12/]. There are already port administrations to collect port dues so adding an additional element to the dues should be quite straightforward. On the other hand there can be technical challenges to calculate emissions and dues, and the effect of such a fee bate system may be limited since the emission level is only one part of a larger dues system, leading to a relatively small differentiation between ships with small or large emissions. Again, the effect on investments by ship owners would depend on the number of ports that introduced such a system and the magnitude of the system. The upside is that such dues attach emission where it does the most harm. 


\section{Taxation of $\mathrm{NO}_{\mathrm{x}}$ emissions}

A charge (tax) on $\mathrm{NO}_{\mathrm{x}}$ emissions is a market-based instrument that may prove efficient. Such a tax can be based on measurement of actual emissions or on emission factors dependent on fuel, and ship and engine type. According to UNCLOS (United Nations Convention on the Law of the Sea) only national sea transport can be exposed to a tax on $\mathrm{NO}_{\mathrm{x}}$ emissions. Denmark levies a tax on $\mathrm{NO}_{\mathrm{x}}$ emissions and in Norway a $\mathrm{NO}_{\mathrm{x}}$ tax funds the $\mathrm{NO}_{\mathrm{x}}$ fund. The Nordic countries could, however, amend and co-ordinate their national $\mathrm{NO}_{\mathrm{x}}$ taxes in such a way that Nordic waters become one homogenous tax area for sea traffic from Nordic countries. Given the present $\mathrm{NO}_{\mathrm{x}}$ regulation in Norway this could take place after 2018, which is the last year of the Norwegian $\mathrm{NO}_{\mathrm{x}}$ fund.

\section{Tradable rights for $\mathrm{NO}_{\mathrm{x}}$ emissions}

A system for emissions trading could be established by setting a cap on $\mathrm{NO}_{\mathrm{x}}$ emissions for ships in Nordic waters, dividing the cap into allowances (also named quotas or emission rights), for instance $1 \mathrm{~kg}$ of $\mathrm{NO}_{\mathrm{x}}$ each, and allocate these allowances to emitters [Ref /11/]. A ship is not allowed to emit more $\mathrm{NO}_{\mathrm{x}}$ than the amount of $\mathrm{NO}_{\mathrm{x}}$ allowances it possesses. When ships buy or sell allowances, the market determines a price to emit one $\mathrm{kg}$ of $\mathrm{NO}_{\mathrm{x}}$. Ships with a relatively low cost of emission reduction will reduce more and sell freed allowances, whereas highcost ships will reduce less and buy allowances. A challenge with tradable rights for $\mathrm{NO}_{\mathrm{x}}$ emissions is to decide which ships should be included in the system. Costal shipping in a Nordic country or between Nordic countries is straightforward. Given IMO regulations it will be difficult to include ships with foreign flags in a trading system, even if they are calling on Nordic ports. Another challenge is reliable methods for monitoring, reporting and verifying $\mathrm{NO}_{\mathrm{x}}$ emissions since not only ship design factors but also ship operational factors determine the emissions. The administrative cost of including the smallest vessels could mean that these should be left out of such a trading system.

Emissions trading leads to a cost-effective solution since all ships face the same price for emitting one more $\mathrm{kg}$ of $\mathrm{NO}_{\mathrm{x}}$. As opposed to a charge on emissions, an emissions trading system fixes the quantity of emissions but allows the price to vary. In theory both the $\mathrm{NO}_{\mathrm{x}}$ price and effect on emissions will be the same for a $\mathrm{NO}_{\mathrm{x}}$ charge (tax) and an emissions trading system.

The efficiency of a $\mathrm{NO}_{\mathrm{x}}$ emissions trading scheme depends on how allowances are distributed. Before the first trading period of a new emission trading system allowances can be auctioned or given out for free, or by combining these methods. Free allocation of allowances induces incentives for building of new ships that do not employ the most effective technology and thus emits too much $\mathrm{NO}_{\mathrm{x}}$. The regulator would need to gather sufficient information to be able to distribute the allowances. The allocation method is in contradiction with the polluters pay principle. 
The incentive effect to reduce emissions, however, remains in the case of free allowances. The most common principle of free allocation is grandfathering, which could easily disproportionally benefit existing ships as opposed to new-builds. Auctioning of allowances can avoid the incentive problems associated with free allowances discussed above. Being faced with the "full" cost of emitting $\mathrm{NO}_{\mathrm{x}}$, instead of just the alternative cost that free allocation represents, ship owners might be more keen to invest in more efficient technologies, as the gains becomes more visible. Even though auctions have to be arranged, this way of allocating allowances requires less administration than free allowances.

\subsubsection{Extension of $\mathrm{NO}_{x}$ and $\mathrm{SO}_{x} \mathrm{ECA}$ areas}

The EU directive allows a Member State to designate special areas as internal waterways, where special emission limits may be applied to the ships sailing through these waters.

DNV is, regardless of ECA status, of the general perception that transfers from ship to air pollutants should be reduced. However, through DNV's investigation [Ref: /4/] on whether the Norwegian and the Barents Sea should become $\mathrm{NO}_{\mathrm{x}}$ an $\mathrm{SO}_{\mathrm{x}}$ ECAs, DNV found no basis for claiming that general MARPOL Annex VI regulations will be efficient means of reducing the national $\mathrm{NO}_{\mathrm{x}}$ and $\mathrm{SO}_{\mathrm{x}}$ emissions, and $\mathrm{DNV}$ cannot see that the Norwegian Sea/Barents Sea represents a relevant candidate area for ECA status. The main reason is that these are scarcely populated areas with limited environmental stress. 


\section{References}

/1/ European Environment Agency 2007. Air pollution in Europe 1990-2004. EEA Report No. 2/2007.

/2/ HELCOM - Baltic NECA application - document 4/4 of HELCOM 32/2011).

/3/ Hordaland Fylkeskommune (Norway) - tender for Alternative propulsion technologies for environmentally friendly car ferries.

/4/ Sjøfartsdirektoratet 2011 - Norskehavet og Barentshavet som særskilt kontrollområde for luftforurensning (ECA - Emission Control Area) under IMO.

/5/ Danish Ministry of the Environment (2012). Reducing air pollution from ships - A cost benefit analysis and feasibility study on possible means for further reduction of emissions. (http://www2.mst.dk/Udgiv/publications/2012/06/97887-92903-11-2.pdf)

/6/ DNV (2010). Greener shipping in the Baltic Sea

(http://www.dnv.fi/Binaries/Greener\%20Shipping\%20in\%20the\%20Baltic\%20 Sea_tcm146-429433.pdf)

/7/ Incentive Partners (2012) Economic Impact Assessment of a $\mathrm{NO}_{\mathrm{x}}$ control area in the North Sea.

/8/ PBL, Netherlands Environmental Assessment Agency (2012), Assessment of the environmental impacts and societal benefits of a nitrogen oxides emission control area in the North Sea.

/9/ HELCOM (2012), HELCOM NECA - Designation of the Baltic Sea as a NO ${ }_{x}$ Emission Control Area.

/10/ DNV (2012) Shipping 2020.

/11/ Torvanger, A., B. Bogstrand, R. B. Skeie, and J. Fuglestvedt (2007). Climate regulation of ships. Report no. 7, CICERO, Oslo.

/12/ Danish Ministry of the Environment (2011). Economic Impact Assessment of a $\mathrm{NO}_{\mathrm{x}}$ emission control area in the North Sea - Terms of Reference. 



\section{Sammendrag}

På vegne av Nordisk Ministerråd har Det Norske Veritas (DNV) gjennomført en studie om mulige kontrollmekanismer for nordiske skipsutslipp. Målet med dette prosjektet er å vurdere utslipp og reduksjonspotensial for regionen og mulige kontrollmekanismer (både insentiver og forskrifter) for å redusere utslippene til luft $\left(\mathrm{NO}_{\mathrm{x}}, \mathrm{PM}^{\circ} \mathrm{Sg}_{\mathrm{x}}\right)$ fra skipsfart i Nordiske farvann. $\mathrm{CO}_{2}$ er ikke tatt med.

\section{Bakgrunn}

Shipping i dag opererer under et komplekst sett av internasjonale og nasjonale forskrifter. Tradisjonelt har utviklingen i regelverk vært styrt av hendelser, og i noen tilfeller hendelser utenfor maritim sektor. Velkjente eksempler er Titanic-ulykken, som til slutt førte til den internasjonale konvensjon om sikkerhet for menneskeliv til sjøs (SOLAS), Exxon Valdez oljeutslippet, som resulterte i Oil Pollution Act (OPA 90), og 11. september terrorangrepet, som resulterte i Havnesikringsforskriften Facility Security (ISPS) Code. Imidlertid har de maritime miljøbestemmelser ligget bak regelverk for landbasert næring. Dette er imidlertid nå i endring.

Den økte oppmerksomheten på både globale og lokale miljøspørsmål generelt, kombinert med økende forståelse av den faktiske forurensningsbelastningen av shipping, har ført til et oppsving i både internasjonale og nasjonale forskrifter. Noen er klare og vil tre i kraft i meget nær fremtid, mens andre fortsatt er under utvikling og vil ha en innvirkning på lengre sikt.

De viktigste spørsmålene for de kommende regelverkene er, grovt sett, svoveloksyder $\left(\mathrm{SO}_{\mathrm{x}}\right)$, nitrogenoksyd $\left(\mathrm{NO}_{\mathrm{x}}\right)$ og partikler $(\mathrm{PM})$, drivhusgasser (særlig $\mathrm{CO}_{2}$ ) og ballastvann.

$\mathrm{SO}_{\mathrm{x}}, \mathrm{NO}_{\mathrm{x}}$ og PM er alle utslipp til luft som følge av forbrenning av marine drivstoff. De lokale miljøeffekter av disse er generelt godt kjent og inkluderer forsuring og overgjødsling, som begge har potensielt alvorlige påvirkning på økosystemet og negative helseeffekter på eksponerte befolkningsgrupper. Dette har i enkelte deler av verden (f.eks. EU og USA) ført til strenge reguleringer av utslipp fra landbaserte kilder. I erkjennelsen av at skipsfarten er blitt en dominerende utslippskilde, potensielt viktigere enn landbaserte kilder, har utslippene blitt regulert internasjonalt av IMO gjennom MARPOL-konvensjonen. Denne er en kombinasjon av generell maksimale globale utslipp samt betydelig 
strengere nivåer som gjelder for dedikerte havområder generelt kjent som Emission Control Areas (ECA). MARPOL-konvensjonen fremmer utslippsreduserende tiltak enten ved å sette krav til drivstoff eller rensing av eksos før utslipp.

\section{Resultater og konklusjon}

\section{Tiltak for å redusere $S_{x}$ utslipp}

IMO har allerede utpekt Østersjøen, Nordsjøen og Den engelske kanal som $\mathrm{SO}_{\mathrm{x}}$ ECA. Veldig snart (2015) vil de aller fleste fartøy som opererer i disse farvannene måtte overholde strenge krav til $\mathrm{SO}_{\mathrm{x}}$-utslipp $(0,1 \%$ svovel drivstoff). Utover dette er det vanskelig å se hvordan $\mathrm{SO}_{\mathrm{x}}$ utslipp kan reduseres ytterligere innenfor ECA områdene når de strengeste kravene trer i kraft i 2015.

Om også Norskehavet/Barentshavet skal bli $\mathrm{NO}_{\mathrm{x}}$ og $\mathrm{SO}_{\mathrm{x}}$ ECA har blitt behandlet som regulativt tiltak. Selv om dette vil resultere i reduserte samlede utslipp, har DNV ikke funnet grunnlag for å hevde at generell MARPOL Annex VI regelverket vil være effektive tiltak for å redusere $\mathrm{NO}_{\mathrm{x}}$ og $\mathrm{SO}_{\mathrm{x}}$-utslipp i denne regionen. Den viktigste grunnen er at området er relativt tynt befolket og har en begrenset miljøbelastning i dag.

\section{Tiltak for å redusere $\mathrm{NO}_{\mathrm{x}}$-utslipp}

Det er forventet at også Østersjøen og Nordsjøen vil bli utpekt som $\mathrm{NO}_{\mathrm{x}} \mathrm{ECA}$ i nær fremtid. Som en følge av dette vil alle fartøy bygget etter 2016 måtte oppfylle de strengeste Tier III utslippskrav for $\mathrm{NO}_{\mathrm{x}}$ (som representerer en $74 \%$ reduksjon i $\mathrm{NO}_{\mathrm{x}}$-utslipp i forhold til dagens Tier II-nivå).

Imidlertid vil alle fartøy bygget før 2016 i praksis være upåvirket av ECA $\mathrm{NO}_{\mathrm{x}}$ regelverket og de vil i et stort antall fortsetter å operere de neste 20-30 årene. Derfor, mens effekten av $\mathrm{SO}_{\mathrm{x}}$ ECA gjennomføringen vil være umiddelbar, vil $\mathrm{NO}_{\mathrm{x}} \mathrm{ECA}$ kravene gradvis ta effekt over de neste 30 årene. Det totale potensialet for reduksjon i $\mathrm{NO}_{\mathrm{x}}$-utslipp fra skipsfart i nordiske farvann er rundt 400000 tonn/år dersom man har et fullt implementert Tier III-regime (forutsatt at dagens andel av Tier III-motorer er nær null).

Det viktigste tiltaket for de Nordiske landene er å aktivt støtte prosessen med $\mathrm{NO}_{\mathrm{x}}$ ECA søknad for Østersjøen og Nordsjøen.

Det er også klart at ytterligere reguleringer/handlinger bør fokusere på fartøy bygget før 2016 og muligens på bestemte fartøygrupper spesielt egnet for regulering. Beregninger av utslipp fra shipping utført i denne studien avdekket at en gruppe fartøy dominerer utslippsbildet. Passasjerskip, og særlig ferger er relativt få i antall, men de er ansvarlig for rundt $30 \%$ av den totale $\mathrm{NO}_{\mathrm{x}}$-utslipp fra skipsfarten. Dette er nesten 3 ganger utslippene fra noen av de andre fartøygruppene. Dette er også skip som kan være un- 
derlagt lisensiert operasjon fra myndighetene og dermed å aktivt stimulere/prioritering Tier III fartøy er potensielt et alternativ.

For fartøy som opererer mellom Nordiske havner er den norske $\mathrm{NO}_{\mathrm{x}}$ Found modellen også en mulighet til å sikre reduserte utslipp. I hovedsak går det ut på at et fartøy kan betale en $\mathrm{NO}_{\mathrm{x}}$-avgift basert på nominelle utslipp enten til Fondet (lav sats) eller til myndighetene (høy sats). Alle medlemmer som betaler inn til fondet er kvalifisert for økonomisk støtte til investeringer med en bevist reduserende effekt på $\mathrm{NO}_{\mathrm{x}}$-utslipp. En slik utvidet $\mathrm{NO}_{\mathrm{x}}$-fond-modell vil måtte fokusere på skip kjølstrukket før 2016 og dermed støtte tiltak på eksisterende fartøy som makinoverhaling og gjenoppbygger, drivstoffbesparende tiltak og ettermontering av teknologier som SCR.

LNG er forventet å være en del av løsningen for å gjøre skip i stand til å oppfylle Tier III kravene og tiltak for å etablere LNG terminaler vil kunne være avgjørende for at flere redere satser på denne typen framdriftsteknologi.

Ser en på aldersfordelingen av flåten som opererer i Nordiske farvann i dag er det klart at en stor andel er gammel tonnasje. Dette gjelder særlig for mindre fartøy som også mest sannsynlig opererer nasjonal eller innenfor Norden. Derfor kan insentiver for å erstatte aldrende skip være en viktig måte å akselerere effektene av et nytt regulatorisk regime. En mulighet er å innføre et system som oppmuntrer til utfasing og erstatning av eldre skip, som kan gjennomføres over en begrenset periode. Et slikt system kan innebære at eieren gjennomfører en kommersiell opphugging av skipet, og som utløser kompensasjon i form av en betaling fra regjeringen.

\section{Tiltak for å redusere $P M / B C$ utslipp}

Partikler (PM) og sot (BC) har kjente negative effekter på både helse og miljø, og mens det er ønskelig å redusere utslippene av disse stoffene, er effekten av mulige tiltak usikre. Utslipp av PM / BC vil kunne forventes å bli redusert med innføringen av et $\mathrm{SO}_{\mathrm{x}}$ ECA (Mindre svovel drivstoff og scrubbere mer vanlig), men forbindelser til type drivstoff er uklar og ikke godt nok kjent. LNG drivstoff vil imidlertid nær kunne eliminere denne typen utslipp. Dermed er tilrettelegging for $ø$ ket bruk av LNG gjennom incentiver/krav til LNG fartøy og bunkringsfaciliteter det potensielt viktigste tiltaket for reduksjon av PM/BC utslipp fra maritime kilder. 
Nordic Council of Ministers

Ved Stranden 18

DK-1061 Copenhagen K

www.norden.org

\section{Control mechanisms for Nordic ship emissions}

Shipping today operates under a complex set of international and domestic regulations. However, the environmental regulations have lagged behind those of other industries. This situation is now changing quite dramatically. The increased focus on environmental issues, combined with the growing realisation of the actual pollution burden imposed by shipping, has led to an upsurge in both international and national regulations. Some are ready and will enter into force in the near future, while others are still being developed.

On behalf of the Nordic Council of Ministers DNV has carried out a study on possible control mechanisms for Nordic ship emission. The aim is to assess the baseline shipping emissions and reduction potential and the possible controlling mechanisms (both incentives and regulations) available for reducing the emissions to air from shipping within the Nordic region. 